\title{
Are benthic fluxes important for the availability of Si in the Gulf of Finland?
}

\section{Tallberg, Petra}

2017-07

Tallberg , P , Heiskanen, A-S, Niemistö , J , Hall , P O J \& Lehtoranta , J 2017 , ' Are benthic fluxes important for the availability of $\mathrm{Si}$ in the Gulf of Finland? ' , Journal of Marine Systems , vol. 171 , pp. 89-100 . https://doi.org/10.1016/j.jmarsys.2017.01.010

http://hdl.handle.net/10138/309474

https://doi.org/10.1016/j.jmarsys.2017.01.010

cc_by_nc_nd

acceptedVersion

Downloaded from Helda, University of Helsinki institutional repository.

This is an electronic reprint of the original article.

This reprint may differ from the original in pagination and typographic detail.

Please cite the original version. 


\section{Accepted Manuscript}

Are benthic fluxes important for the availability of Si in the Gulf of Finland?

Petra Tallberg, Anna-Stiina Heiskanen, Juha Niemistö, Per O.J. Hall, Jouni Lehtoranta

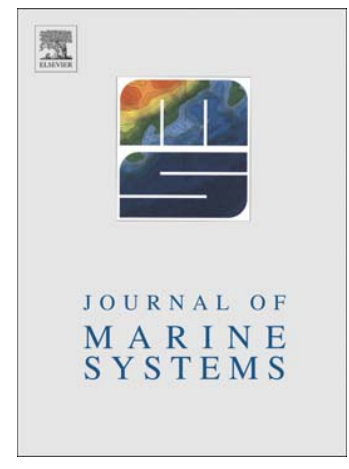

PII: $\quad$ S0924-7963(17)30020-9

DOI: $\quad$ doi: $10.1016 /$ j.jmarsys.2017.01.010

Reference: $\quad$ MARSYS 2938

To appear in: Journal of Marine Systems

Received date: $\quad 13$ April 2016

Revised date: $\quad 11$ January 2017

Accepted date: $\quad 12$ January 2017

Please cite this article as: Tallberg, Petra, Heiskanen, Anna-Stiina, Niemistö, Juha, Hall, Per O.J., Lehtoranta, Jouni, Are benthic fluxes important for the availability of Si in the Gulf of Finland?, Journal of Marine Systems (2017), doi:10.1016/j.jmarsys.2017.01.010

This is a PDF file of an unedited manuscript that has been accepted for publication. As a service to our customers we are providing this early version of the manuscript. The manuscript will undergo copyediting, typesetting, and review of the resulting proof before it is published in its final form. Please note that during the production process errors may be discovered which could affect the content, and all legal disclaimers that apply to the journal pertain. 


\title{
Are benthic fluxes important for the availability of $\mathrm{Si}$ in the Gulf of Finland?
}

\author{
Petra Tallberg ${ }^{1}$, Anna-Stiina Heiskanen ${ }^{2}$, Juha Niemistö ${ }^{3}$, Per O.J. Hall ${ }^{4} \&$ Jouni Lehtoranta $^{2}$ \\ ${ }^{1}$ Department of Environmental Sciences, PO Box 65, 00014 University of Helsinki, Finland and Tvärminne \\ Zoological Station, J.A. Palmenin tie 260, 10900 Hanko, Finland, petra.tallberg@ helsinki.fi (corresponding \\ author) \\ ${ }^{2}$ Finnish Environment Institute/Marine Research Centre, P.O. Box 140, 00251 Helsinki, Finland, anna- \\ stiina.heiskanen@ymparisto.fi, jouni.lehtoranta@ymparisto.fi, \\ ${ }^{3}$ Department of Environmental Sciences, PO Box 65, 00014 University of Helsinki, Finland, \\ juha.niemisto@helsinki.fi \\ ${ }^{4}$ Department of Marine Sciences, University of Gothenburg, SE-412 96 Gothenburg, Sweden, \\ perhall@chem.gu.se
}

\begin{abstract}
We estimated the efflux of dissolved silicon (DSi) from sediments in the Gulf of Finland and compared it to sedimentation fluxes, burial of Si and existing data on Si loading and stocks, reassessing the reliability of existing Si budgets. Benthic fluxes of DSi measured in situ and in vitro were several times higher than estimates from diffusion calculations. The spatial variability in the open Gulf of Finland was relatively small, while both very high and low fluxes were measured from coastal areas. Fluxes were highest in late summer and lowest in early spring. In our re-assessed budget we present a new lower estimate for Si burial in the sediments, ca $6 \mathrm{Gmol} \mathrm{a}^{-1}$ and show that more than half of the sedimentation flux of $\mathrm{Si}$ is released back into the water column. Changes in the efficiency of internal DSi recycling may thus affect the prevalence of siliceous phytoplankton within the ecosystem, and the diatom spring bloom may be regulated by the functioning of this internal recycling pump. We also show that the seasonal variation in benthic DSi fluxes and dissolved phosphate fluxes is similar, and that a tentative connection between hypoxia and high DSi efflux exists.
\end{abstract}

\section{Keywords}

Silicon, sediment, Baltic Sea, benthic flux

\section{Introduction}

The supply of silicon ( $\mathrm{Si}$ ) is an important qualitative factor for the phytoplankton communities in most water bodies. If $\mathrm{Si}$ is available in sufficient amounts, Si-requiring phytoplankton, mainly diatoms (Bacillariophyceae), may be one of the most prolific primary producers (e.g. Willen 1991, Reynolds 1994). As cold-water specialists, diatoms generally 
produce high biomasses during periods of turbulence, high light, low temperature and high supply of nutrients, e.g. spring blooms after the winter and ice-covered period at high latitudes. In the Baltic Sea, the role of the diatoms in the phytoplankton succession is especially topic, as there is strong competition between diatoms and dinoflagellates for dominance within the spring bloom (Wasmund \& Uhlig 2003, Klais et al. 2011, 2013, Wasmund et al. 2011). While several reasons for the unusual abundance of dinoflagellates in the spring have been proposed (see Stipa 2002, Spilling 2007, Kremp et al. 2008, Klais et al. 2011, 2013, Wasmund et al. 2013), the supply of Si and changes affecting it is one factor that may favour dinoflagellates at the diatoms' expense (cf. Danielsson et al. 2008, Papush et al. 2009, Spilling et al. 2010, Wasmund et al. 2013, Danielsson 2014).

Several Si budgets have been drawn up for the Baltic Sea using various approaches (Wulff \& Stigebrandt 1989, Wulff et al. 1994, 2001, Savchuk 2002, Conley et al. 2008, Papush et al. 2009). As a rule, the budgets have used simplistic box models, where Si is supplied by river runoff and removed by uptake and sedimentation of, mainly, diatoms, and by outflow through the Danish Straits into the Atlantic. Interestingly, regeneration of Si from the sediment surface is not generally taken into account, even though diatom frustules are made of amorphous, biogenic silica (ASi) with a comparatively high dissolution rate (e.g. Hurd 1983), and the sedimentation of ASi is only a semi-permanent sink for $\mathrm{Si}$, especially in shallow waters (cf, Conley \& Malone 1992). In the budgets, this problem has mostly been dealt with by using measurements of ASi from the sediment and considering this the buried part of the supplied Si. It is quite clear, however, that this produces only a very rough indication of the burial of Si with, in addition, a temporal bias. It takes several years if not decades for the surface sediment to stabilize and even then, some ASi continues to dissolve and be transformed by diagenetic processes (for instance Michalopoulos \& Aller 2004, Gallinari et al. 2002, 2008, Presti \& Michalopoulos 2008). It has, further, proven problematic to balance the Si models for the Baltic Sea (Conley et al. 2008, Papush et al. 2009), and it is clear that both the external loading of $\mathrm{Si}$ and the $\mathrm{Si}$ cycling within the system itself need further clarification. The benthic flux of dissolved Si (DSi), its local and seasonal variability, and the processes involved need further study and, especially, quantification. Although measurements of sedimentary Si fluxes in the Baltic Sea have been published (Balzer 1984, Sundbäck et al. 1991, Conley \& Johnstone 1995, Conley et al. 1997, Karlson et al., 2005, Tallberg et al. 2013, Villnäs et al. 2013, Norkko et al. 2015, Ekeroth et al. 2016a,b), the causalities behind the fluxes have in general not been thoroughly explored. 
The objective of this study is to produce an estimate of the benthic flux of Si from sediments in the Gulf of Finland and to compare these fluxes to existing data on Si loading, stocks and burial in the area, and evaluate the importance of Si release from sediments for the reliability of existing Si models for the Baltic Sea. We hypothesize that the accumulation of ASi at the sediment surface is high, and that this leads to high concentrations of $\mathrm{Si}$ in the sediment pore water and to high effluxes of Si into the bottom water. This means that on a short-term basis, the bioavailable Si pool in the water column of the Gulf of Finland is strongly governed by the mobilization of $\mathrm{Si}$ from the bottom sediments. This has multiple implications for the seasonal nutrient limitation patterns and phytoplankton composition in the Gulf of Finland and the Baltic Sea.

\section{Material and methods}

\subsection{Study area}

The Gulf of Finland is one of the main basins of the semi-enclosed Baltic Sea, with an area of ca $30000 \mathrm{~km}^{2}$, a water volume of ca $1000 \mathrm{~km}^{3}$, maximum and average depths of ca 123 and $37 \mathrm{~m}$, respectively, and a water residence time of ca 3 a (Alenius et al. 1998, Andersen et al. 2015, Fig. 1). The Gulf is, hydrographically, a semi-stratified estuary, influenced quite heavily both by saline water inflow from the Baltic Proper and by freshwater loading from rivers, most notably the Neva, which alone accounts for almost $75 \%$ of the freshwater inflow into the Gulf. The salinity conditions in the Gulf vary between almost freshwater in the surface waters in the East and in the immediate coastal zone and up to 9 PSU in the deep water layers in the western part of the Gulf, where the water column is salinity stratified with a halocline at $60-80 \mathrm{~m}$ depth (Alenius et al. 1998). The Gulf has been subjected to quite severe nutrient loading from both point-sources (e.g. the cities of Helsinki, St Petersburg and Tallinn together with industrial complexes) and diffuse sources (agriculture), and is one of the more eutrophic parts of the Baltic Sea (e.g. Andersen et al. 2015): Average (2007-2011) wintertime dissolved inorganic nitrogen and phosphorus concentrations were ca 8.1 and 0.9 $\mu$ mol $1^{-1}$, respectively (surface water, HELCOM 2014).

\subsection{Sampling}


The seasonal variation in benthic fluxes and pore water concentrations of Si were measured from two stations on the Northern coast of the Gulf of Finland near Tvärminne Zoological Station: Storfjärden (59 $51.34,23^{\circ} 15.75$, depth $\left.33 \mathrm{~m}\right)$ and Storgadden $\left(59^{\circ} 47.40,23^{\circ} 20.37\right.$, depth 51 m; Fig. 1, Table 1) between May 26, 1999 and March 27, 2000. Spatial variability of Si sediment-water fluxes in the open (Southern) and coastal Gulf of Finland was in addition assessed at cruises with R/V Muikku (Table 1) in 2001, 2002 and 2004. In addition, DSi flux measurements were made in situ in May and August, 2014, in Storfjärden using the small "Göteborg” benthic lander (cf. Tengberg et al. 2003).

For the seasonal and spatial measurements, sediment cores were taken with gravity corers and water samples using a standard tube sampler. Some intact cores were preserved under as in situ conditions as possible and used for flux measurements (see below), while some were sliced into 0.5 or $1 \mathrm{~cm}$ slices and used for pore water extraction and ASi samples. The water samples were analysed for DSi according to standard methods (ammonium-blue molybdate reaction and spectrophotometry, Mullin \& Riley 1955). Oxygen concentrations in the bottom water were measured either by Winkler titration or with a WTW Microprocessor Oximeter OX196 electrode. Sediment pore water was extracted from sediment cores using (1) rhizon filters (Storfjärden 2014 samples; Rhizon CSS, $0.2 \mu \mathrm{m}$ pore size, polyethersulfon membrane, Rhizosphere Research Products, Netherlands), (2) centrifugation (10 min,10000 rpm) followed by pressure filtration ( $0.4 \mu \mathrm{m}$ polycarbonate membranes, coastal samples) or (3) pressure filtration only (spatial, open Gulf of Finland samples). The samples were analysed for DSi as described above. 
Table 1. The measured and calculated (diffusive) sediment-water fluxes of DSi from the studied stations as well as the ratio measured:diffusive flux. The measured in situ fluxes (from the benthic landers) are marked with $*$. The diffusive fluxes were calculated using the concentration difference between either the top sediment centimeter and the bottom water (or with the aid of the slope of the pore water DSi profiles and polynomial regression equations; see text for details).

\begin{tabular}{|c|c|c|c|c|c|c|c|c|c|c|c|c|}
\hline Site & Station & Date & Coordinates & & $\underset{\mathrm{m}}{\operatorname{Dmax}}$ & Salinity & $\begin{array}{c}\text { Bottom } \\
\text { water } \mathrm{O}_{2} \\
\text { umol 1 }^{-1}\end{array}$ & $\begin{array}{c}\text { Measured } \\
\text { flux } \\
\mathrm{Si}, \mathrm{mmol} \mathrm{m}_{2} \mathrm{~d}^{-1}\end{array}$ & $\begin{array}{c}\text { Diffusive } \\
\text { flux (A) } \\
\mathrm{Si},{ }_{{ }_{2} \mathrm{~d}^{-1}} \mathrm{~m}^{-}\end{array}$ & $\begin{array}{c}\text { Diffusive } \\
\text { flux (B) } \\
\mathrm{Si}, \mathrm{mmol}^{-2} \mathrm{~d}^{-1}\end{array}$ & $\begin{array}{c}\text { Diffusive } \\
\text { (average) } \\
\mathrm{Si}, \mathrm{mmol} \\
\mathrm{m}^{-2} \mathrm{~d}^{-1}\end{array}$ & $\begin{array}{l}\text { Incubated: } \\
\text { diffusive }\end{array}$ \\
\hline \multirow[t]{2}{*}{ Storfjärden } & $7 \mathrm{~m}$ & 28.4 .2014 & 595111 & 231446 & 7 & 5.7 & 375 & 2.7 & 0.1 & 0.5 & 0.3 & 8.7 \\
\hline & & 29.7.2014 & 595111 & 231446 & 7 & 5.7 & 209 & 3.3 & 0.3 & 1.0 & 0.6 & 5.4 \\
\hline \multirow[t]{2}{*}{ Storfjärden } & $20 \mathrm{~m}$ & 28.4 .2014 & 595121 & 231501 & 20 & 5.9 & 375 & 2.7 & 0.2 & 0.0 & 0.1 & 35 \\
\hline & & 29.7.2014 & 595121 & 231501 & 20 & 6.3 & 216 & 1.9 & 0.2 & 0.3 & 0.2 & 7.9 \\
\hline \multirow[t]{9}{*}{ Storfjärden } & $33 \mathrm{~m}$ & 27.4.1999 & 595134 & 231575 & 33 & 5.7 & 297 & -0.4 & n.a. & 0.2 & 0.2 & -2.3 \\
\hline & & 24.5.1999 & 595134 & 231575 & 33 & 5.9 & 238 & 0.6 & n.a. & 0.1 & 0.1 & 12 \\
\hline & & 7.6.1999 & 595134 & 231575 & 33 & 6.5 & 244 & 0.4 & n.a. & 0.2 & 0.2 & 1.9 \\
\hline & & 19.7.1999 & 595134 & 231575 & 33 & 6.2 & 144 & 1.5 & n.a. & 0.1 & 0.1 & 20 \\
\hline & & 30.8 .1999 & 595134 & 231575 & 33 & 6.1 & 219 & 0.9 & n.a. & 0.2 & 0.2 & 5.1 \\
\hline & & 27.9.1999 & 595134 & 231575 & 33 & 5.9 & 253 & 0.6 & n.a. & 0.2 & 0.2 & 4.1 \\
\hline & & 25.10 .1999 & 595134 & 231575 & 33 & 6.2 & 284 & 0.5 & n.a. & 0.1 & 0.1 & 3.5 \\
\hline & & 10.1 .2000 & 595134 & 231575 & 33 & 6.2 & 344 & 0.5 & n.a. & 0.1 & 0.1 & 7.3 \\
\hline & & 27.3 .2000 & 595134 & 231575 & 33 & 6.1 & n.a. & 0.9 & n.a. & 0.2 & 0.2 & 5.4 \\
\hline \multirow[t]{6}{*}{ Storgadden } & & 7.6.1999 & 594740 & 232037 & 51 & 6.9 & 241 & 0.6 & n.a. & 0.1 & 0.1 & 5.6 \\
\hline & & 19.7.1999 & 594740 & 232037 & 51 & 7.1 & 159 & 1.3 & n.a. & 0.2 & 0.2 & 7.1 \\
\hline & & 30.8 .1999 & 594740 & 232037 & 51 & 7.2 & 16 & 1.5 & n.a. & 0.2 & 0.2 & 8.5 \\
\hline & & 27.9.1999 & 594740 & 232037 & 51 & 6.9 & 238 & 0.9 & n.a. & n.a. & n.a. & n.a. \\
\hline & & 10.1 .2000 & 594740 & 232037 & 51 & 6.5 & 250 & 0.8 & n.a. & 0.3 & 0.3 & 2.9 \\
\hline & & 27.3.2000 & 594740 & 232037 & 51 & 6.4 & n.a. & 0.3 & n.a. & 0.3 & 0.3 & 1.1 \\
\hline
\end{tabular}


Ahvenkosken-

\begin{tabular}{|c|c|c|c|c|c|c|c|c|c|c|c|c|}
\hline \multirow[t]{7}{*}{ lahti } & AHLA9 & 23.8 .2004 & 602414 & 262972 & 12 & 4.5 & 136 & 3.2 & 0.6 & 0.7 & 0.6 & 5.3 \\
\hline & AHLA3 & 24.8.2004 & 602677 & 262976 & 4 & 3.9 & 140 & 2.9 & 0.4 & -0.3 & 0.0 & 59 \\
\hline & AHLA6 & 24.8 .2004 & 602530 & 262862 & 6.8 & 4.3 & 154 & 3.1 & 0.2 & 0.2 & 0.2 & 15 \\
\hline & AHLA2 & 25.8 .2004 & 602741 & 262894 & 3.2 & 3.7 & 277 & 1.8 & 0.1 & 0.0 & 0.0 & 37 \\
\hline & AHLA1 & 25.8 .2004 & 602832 & 262827 & 2 & 0.0 & 256 & 0.6 & 0.2 & -0.1 & 0.0 & 17 \\
\hline & AHLA5 & 24.8 .2004 & 602544 & 263243 & 4.3 & 0.7 & 295 & 4.9 & 0.3 & 0.3 & 0.3 & 18 \\
\hline & AHLA9 & 26.8.2004 & 602414 & 262972 & 12 & 4.3 & 194 & 2.2 & 0.4 & 0.2 & 0.3 & 7.4 \\
\hline \multicolumn{13}{|l|}{ Coastal } \\
\hline \multirow[t]{11}{*}{ Northern Gulf } & Rankki MN & 31.8 .2001 & 601869 & 265924 & 42 & n.a. & n.a. & -0.1 & n.a. & n.a. & n.a. & n.a. \\
\hline & Rankki QR & 31.8.2001 & 601982 & 265804 & 38 & n.a. & n.a. & -0.1 & n.a. & n.a. & n.a. & n.a. \\
\hline & Rankki EF & 31.8.2001 & 601984 & 270153 & 38 & 6.2 & n.a. & -0.1 & n.a. & n.a. & n.a. & n.a. \\
\hline & KAS3 & 3.9.2001 & 601961 & 265373 & 44 & 6.0 & n.a. & 0.2 & n.a. & n.a. & n.a. & n.a. \\
\hline & RistisaariS & 4.9.2001 & 601527 & 265000 & 45 & 5.6 & n.a. & 0.00 & n.a. & n.a. & n.a. & n.a. \\
\hline & KotkaMajakka & 4.9.2001 & 600798 & 263518 & 60 & 7.4 & n.a. & 0.02 & n.a. & n.a. & n.a. & n.a. \\
\hline & LL3A & 2001 & 600405 & 262071 & 61 & 7.8 & n.a. & 0.04 & n.a. & n.a. & n.a. & n.a. \\
\hline & SandöfjärdBA & 18.8.2001 & n.a. & n.a. & n.a. & n.a. & n.a. & 0.6 & n.a. & n.a. & n.a. & n.a. \\
\hline & SandöfjärdDC & 18.8.2001 & 595334 & 233599 & 26 & n.a. & n.a. & 0.2 & n.a. & n.a. & n.a. & n.a. \\
\hline & $\begin{array}{l}\text { SandöfjärdHG } \\
\text { Sandöfjärd }\end{array}$ & 18.8.2001 & 595363 & 233658 & 29 & n.a. & n.a. & 0.1 & n.a. & n.a. & n.a. & n.a. \\
\hline & LK & 18.8.2001 & 595392 & 233664 & 19 & n.a. & n.a. & -0.1 & n.a. & n.a. & n.a. & n.a. \\
\hline \multirow[t]{6}{*}{ Southern Gulf } & V39 & 20.8.2002 & 593499 & 242197 & 83 & 9.6 & 32 & 1.2 & 0.2 & 0.3 & 0.2 & 5.0 \\
\hline & V45 & 20.8.2002 & 592336 & 234323 & 77 & 9.2 & 118 & 1.1 & 0.2 & 0.2 & 0.2 & 5.1 \\
\hline & V42 & 21.8.2002 & 593446 & 240788 & 89 & 9.2 & 32 & 0.8 & 0.2 & 0.1 & 0.2 & 5.5 \\
\hline & V23 & 26.8.2002 & 594999 & 252104 & 83 & 8.9 & 41 & 0.7 & 0.3 & 0.1 & 0.2 & 3.2 \\
\hline & V4 & 27.8.2002 & 593545 & 265620 & 53 & 6.8 & 256 & 1.0 & 0.2 & 0.2 & 0.2 & 5.3 \\
\hline & V10 & 28.8.2002 & 594299 & 262199 & 72 & 7.8 & 183 & 1.4 & 0.3 & 0.2 & 0.3 & 5.4 \\
\hline
\end{tabular}


Biogenic or amorphous $\mathrm{Si}$ (here termed $\mathrm{ASi}$ ) was extracted from dried, mortar-ground sediment samples (core length $0-15 \mathrm{~cm}$, depth resolution $1 \mathrm{~cm}$-slices) from the spatialvariability sediment cores taken from the southern Gulf of Finland and from surface sediment samples from Storfjärden. The samples were extracted using $0.1 \mathrm{M} \mathrm{Na}_{2} \mathrm{CO}_{3}$ at $85^{\circ} \mathrm{C}$ with a mineral correction based on the different solubility with time of mineral and biogenic, amorphous Si. The procedure has been modified after DeMaster (1981) and a closer description of it can be found in Tallberg et al. (2012). After extraction, the obtained DSi samples were analysed as described above.

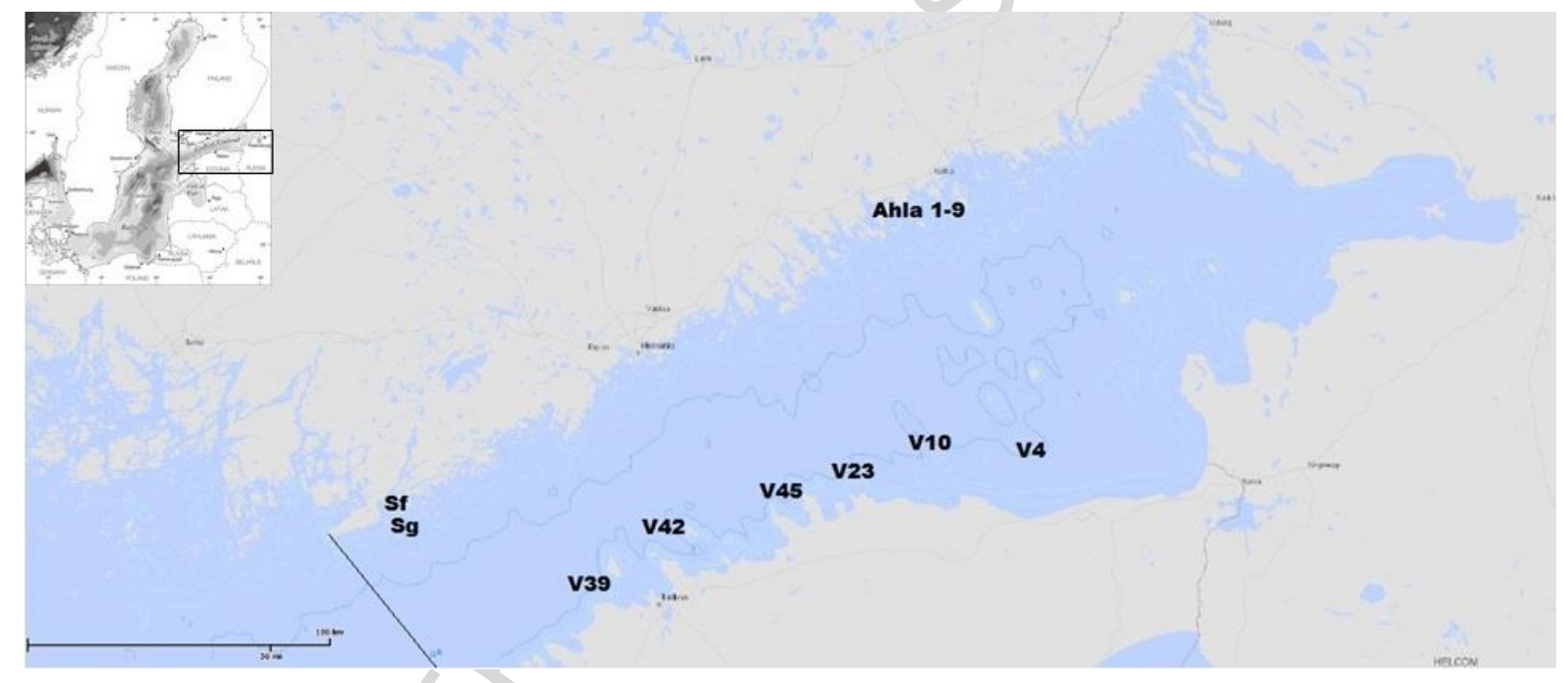

Fig. 1. The Gulf of Finland, its location in the Baltic Sea, and the approximate location of the sampled stations (see Table 1 for closer coordinates). SG= Storgadden, SF=Storfjärden, Sandö = stations in Sandöfjärden, AHLA 1-9 = stations in Ahvenkoskenlahti, NE 1-6 = stations in the coastal Northeastern Gulf (see Table 1). The baseline maps originate from Tikkanen \& Oksanen (2002, the Baltic Sea) and the HELCOM data bases (Gulf of Finland, accessed 17.11.2015). The blue isobar denotes the area deeper than $50 \mathrm{~m}$.

\subsection{Benthic fluxes}

Benthic fluxes were estimated in three ways, i.e. (1) via in vitro incubations of intact sediment cores, (2) with a benthic lander (in situ), and (3) with the aid of pore water DSi measurements and Fick's law of diffusion. The in vitro incubations were done using polycarbonate tubes (diameter $74 \mathrm{~mm}$ ) which were incubated in a flow-through system at in situ temperature in the dark. The cores were pre-incubated for 60 hours in order to obtain stable conditions before samples were taken. Each core (3-4 replicates) was covered by ca $400 \mathrm{ml}$ of near-bottom water stirred by magnetic stirrers at a speed below the resuspension 
limit (visually estimated). The flow-through system used unfiltered, near-bottom water from the sampling stations and a peristaltic pump kept the water flow at 0.4-0.5 $\mathrm{ml} \mathrm{min}^{-1}$. When the oxygen concentration in situ was low (Storgadden, August, $4.5 \mathrm{mg}^{-1}$ ), the inflowing water was bubbled with $\mathrm{N}_{2}$-gas to maintain the concentration, otherwise, the in situ $\mathrm{O}_{2}$ concentrations of the water (8-12 $\mathrm{mg} \mathrm{l}^{-1}$ ) were unmanipulated. Water samples were taken from the in- and out-flowing water, filtered through $0.4 \mu \mathrm{m}$ polycarbonate membranes and analysed for $\mathrm{Si}$ as above. The benthic flux was calculated using the concentration difference between the in- and outflowing water related to the sediment surface area and flow rate. A more detailed description of the procedure can be found in Lehtoranta \& Heiskanen (2003).

The benthic lander measurements were made using the small "Göteborg" lander with two open-bottomed incubation chambers of $400 \mathrm{~cm}^{2}$ area each. The lander was lowered to the sea floor very slowly to avoid disturbing the surface sediment, and the buoyancy of the lander adjusted to reach an appropriate volume of the chambers. The chamber lids were kept open during the lowering to flush away the water from shallower depths. To enhance this flushing the landers were also pumped up and down a few times in the water column before lowering to the sediment. Incubations were conducted at two stations $(7 \mathrm{~m}$ and $20 \mathrm{~m})$ within the Storfjärden basin. Three deployments were conducted in May and four in August 2014. In each deployment, the incubation of each chamber consisted of a $3 \mathrm{~h}$ pre-incubation period (lids open) and a $12 \mathrm{~h}$ experiment phase. Slow stirring with a horizontal Mississippi type paddle wheel placed centrally in the chambers was maintained during both the pre-incubation and the experiment phase. The pre-incubation period further allowed ambient bottom water conditions regarding e.g. oxygen concentration to be established in the chambers. Water samples for the benthic DSi flux calculations were withdrawn at the beginning of the incubation and every $1.4 \mathrm{~h}$. The sampled water was replaced by bottom water that entered passively from outside through a coil in the lid of the chamber. After the recovery of the landers, water samples were immediately filtered through prewashed cellulose acetate membrane filters of $0.45 \mu \mathrm{m}$ pore size (VWR International, USA) and analysed for DSi as above. The benthic fluxes of DSi $\left(\mathrm{mmol} \mathrm{m}^{-2} \mathrm{~d}^{-1}\right)$ were calculated based on the concentration change over time in each incubation chamber by fitting the least square regression model to these data and multiplying the obtained slope of the regression (if $p<0.05$ ) by the volume, and dividing with the bottom area, of the chamber. The inflow of ambient bottom water into the chambers when withdrawing samples was corrected for before the benthic fluxes were calculated. More detailed descriptions of the operation of this lander can be found in Ekeroth 
et al. (2016a,b). The chambers of the small "Göteborg" lander are identical to those of the autonomous big "Göteborg" lander, which has been described previously (e.g. Tengberg et al. 2004; Ståhl et al. 2004; Almroth et al. 2009).

For some of the spatial variability samples, benthic fluxes of DSi were also estimated from pore water gradients using Fick's first law of diffusion according to Märtz et al. (2015). Here, the diffusion of DSi $\left(\mathrm{mol} \mathrm{m}^{-2} \mathrm{~s}^{-1}\right)$ was estimated as

$$
\mathrm{J}=\Phi * \mathrm{D}_{\text {sed }} * \frac{d c}{d x}
$$

where $\Phi=$ sediment porosity, $\mathrm{D}_{\text {sed }}=$ sediment diffusion coefficient for DSi $\left(\mathrm{m}^{2} \mathrm{~s}^{-1}\right), \mathrm{dc}=$ the concentration difference at the sediment-water interface $\left(\mathrm{mol} \mathrm{m} \mathrm{m}^{-2}\right)$ and $\mathrm{dx}=$ the diffusion distance $(\mathrm{m})$. The diffusion distance $\mathrm{dx}$ used was 0.005 or $0.01 \mathrm{~m}$, depending on the resolution of the pore water measurements. The concentration gradient dc was estimated either as the difference between the DSi concentration in the topmost sediment layer and the bottom water (when both measurements were available) or from the pore water DSi concentration gradient with the aid of regression equations (MS Excel 2013); the best fit (always $r^{2}>0.90$ ) was generally achieved with polynomial $2^{\text {nd }}$ degree or power functions.

Sediment porosity $\Phi$ was estimated from total sediment mass $(\mathrm{Wt})$ and sediment dry mass (Ws) according to Sarazin et al. (1995):

$$
\Phi=\left\lceil 1+\frac{W s}{2.5(W t-W s)}\right\rceil^{-1}
$$

and $\mathrm{D}_{\text {sed }}$ according to Clavero et al. (1992):

$$
\mathrm{D}_{\text {sed }}=\frac{D_{i} * \Phi^{3}}{1.28}
$$

$\mathrm{D}_{\mathrm{i}}$ is the molar diffusion coefficient for DSi at $+2^{\circ} \mathrm{C}, 5 * 10^{-10} \mathrm{~m}^{2} \mathrm{~s}^{-1}$ (Schulz 2006).

\subsection{Sedimentation fluxes}

Sedimentation of biogenic $\mathrm{Si}$ (ASi) was estimated using sediment traps moored below the productive layer at $20 \mathrm{~m}$ at Storfjärden and Storgadden during one seasonal cycle in 1992 (March-November). The traps consisted of duplicate cylinders $(100 * 10 \mathrm{~cm}$, aspect ratio 10) and were emptied weekly from March to May and every second week thereafter. The traps and the sampling setup are described in more detail in Heiskanen \& Tallberg (1999). Samples 
for particulate biogenic silica (ASi) analysis were taken from the sediment trap samples, filtered on polycarbonate filters (Nuclepore, pore size $1 \mu \mathrm{m}$ ) and stored frozen. The ASi content of the samples was determined by hydrolysis in dilute $(0.5 \%) \mathrm{Na}_{2} \mathrm{CO}_{3}$ solution (Paasche 1980), and the samples were analysed for DSi using the ammonium-blue-molybdate method according to Koroleff (1983).

\subsection{Loading and stocks}

Data on Si concentrations in the water column of the Gulf of Finland (56 stations, total number of observations $=32516$, time period 1958-2013) and on the riverine load from the largest Finnish rivers discharging into the Gulf of Finland (7 rivers, total number of observations $=2083$, time period 1970-2010) were obtained from the databases at the Finnish Environment Institute (SYKE). The rivers were Kymijoki, Karjaanjoki, Vantaanjoki, Porvoonjoki, Mustijoki, Taasianjoki and Virojoki. Data on the Si load from the (largest) Russian and Estonian rivers discharging into the Gulf of Finland (Narva, Neva and Kaila rivers) were obtained from Humborg et al. (2008).

\subsection{Budget calculations}

A simple yearly Si budget for the Gulf of Finland was calculated from externally obtained data with the aid of some extrapolations. The input fluxes consisted of external loading of DSi (SYKE databases and Humborg et al. 2008) and ASi (Lehtimäki et al. 2013) and of the estimates for DSi exchange with the Baltic Proper presented by Papush et al. (2009). In the absence of more comprehensive ASi loading data for the whole Gulf, the load of ASi was extrapolated from the data measured by Lehtimäki et al. (2013) from one of the rivers discharging into the Gulf, Vantaanjoki. We assumed that the proportion of DSi to ASi in the total load of potentially bioavailable $\mathrm{Si}$ (here defined as DSi+ASi) is constant in all the rivers, and estimated the load of $\mathrm{ASi}\left(\mathrm{ASi}_{1}\right)$ for each river from this relationship and from the DSi load from each river, i.e.:

$A S i_{l}=\frac{A S i_{v}}{A S i_{v}+D S i_{v}} * D S i_{l}$

$\mathrm{ASi}_{1}=$ the load of ASi from each river $\left(\mathrm{mmol} \mathrm{d}^{-1}\right)$

$\mathrm{ASi}_{\mathrm{v}}=$ the average concentration of ASi in River Vantaa $\left(\mathrm{mmol} \mathrm{m}{ }^{-3}\right)$ 
$\mathrm{DSi}_{\mathrm{v}}=$ the average concentration of DSi in River Vantaa $\left(\mathrm{mmol} \mathrm{m}^{-3}\right)$

$\mathrm{DSi}_{1}=$ the load of DSi from the river in question $\left(\mathrm{mmol} \mathrm{d}^{-1}\right)$

The average proportion of ASi in the bioavailable Si load in River Vantaa was $42 \%$ (Lehtimäki et al. 2013). The yearly load (expressed as $\mathrm{Gmol} \mathrm{a}^{-1}$ of Si) was obtained by multiplying the daily load by 365 . Output of Si was estimated as the outflow of DSi into the Baltic Proper (Papush et al. 2009) and the burial of ASi in the sediments. Yearly ASi burial $\left(\mathrm{ASi}_{\mathrm{b}}, \mathrm{Gmol} \mathrm{a}^{-1}\right.$ of $\mathrm{Si}$ ) was calculated as:

$A S i_{b}=\frac{A S i_{S}}{S A R} * A$

$\mathrm{ASi}_{\mathrm{b}}=$ yearly ASi burial $\left(\mathrm{Gmol} \mathrm{a}^{-1}\right)$

$\mathrm{ASi}_{\mathrm{S}}=$ the average concentration of ASi in the surface $(0-10 \mathrm{~cm})$ sediment layer $\left(\mathrm{mmol} \mathrm{g} \mathrm{g}^{-1}\right.$ DM, dry mass)

$\mathrm{SAR}=$ the median sediment accumulation rate in the Gulf of Finland $\left(690 \mathrm{~g} \mathrm{~m}^{-2} \mathrm{a}^{-1}\right.$, range 140-2950 $\mathrm{g} \mathrm{m}^{-2} \mathrm{a}^{-1}, \mathrm{n}=53$, Mattila et al. 2006)

For A, either the entire area of the Gulf of Finland, $30000 \mathrm{~km}^{2}\left(3 * 10^{10} \mathrm{~m}^{2}\right.$, Alenius et al. 1998), or only the accumulation area $\left(10500 \mathrm{~km}^{2}\left(10.5^{*} 10^{10} \mathrm{~m}^{2}\right.\right.$, estimated based on Kankaanpää et al. 1997 and Lehtoranta 2003), was used. The internal recycling of potentially bioavailable Si was, further, estimated with the aid of the measured sediment-water fluxes of DSi and the sedimentation fluxes of ASi. Yearly fluxes $\left(\mathrm{Gmol} \mathrm{a}^{-1}\right)$ for the whole Gulf were obtained from average measured fluxes $\left(\mathrm{mmol} \mathrm{m}^{-2} \mathrm{~d}^{-1}\right)$ by multiplying with $365(\mathrm{~d})$ and either the area of the entire Gulf or the accumulation area (as above).

The area-weighted water column stock of DSi (Gmol) was estimated from the average DSi concentration in the water column (52 stations, $D_{\max } 9-90 \mathrm{~m}, 28675$ observations), the depth at the sampling station and the area of the Gulf of Finland $\left(3^{*} 10^{10} \mathrm{~m}^{2}\right.$, Alenius et al. 1998). Statistical analyses (correlation, regression) were performed using MS Excel 2013. 


\section{Results}

\subsection{Pore water concentrations and $\mathrm{ASi}$}

The pore water concentration of DSi increased with sediment depth at all stations. The surface values varied between 53 (Storfjärden) and 250 (AHLA 9) $\mu$ mol $1^{-1}$ and values of up to $650 \mu \mathrm{mol}^{-1}$ were found at 7-10 $\mathrm{cm}$ depth (AHLA 9, Fig. 2).

A.

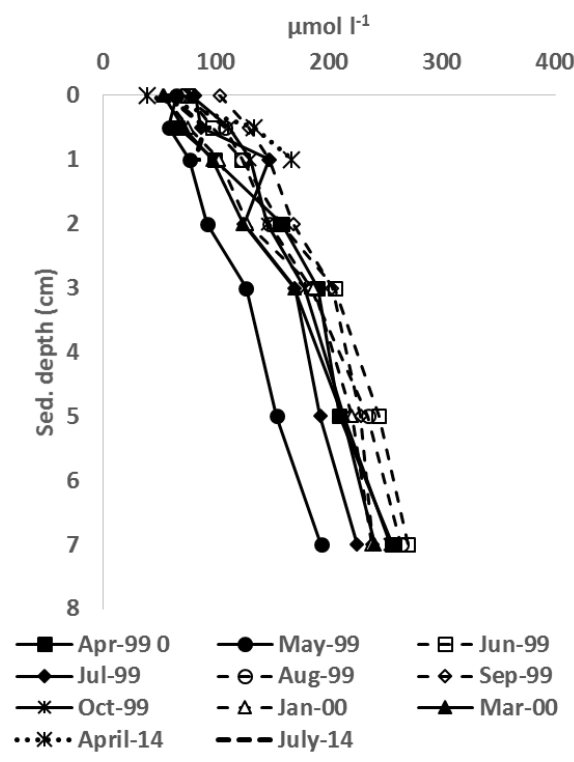

C.

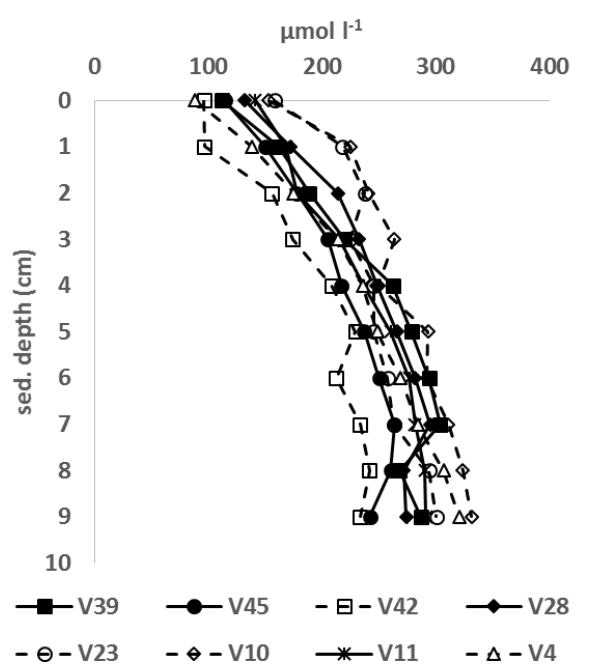

B. Storgadden

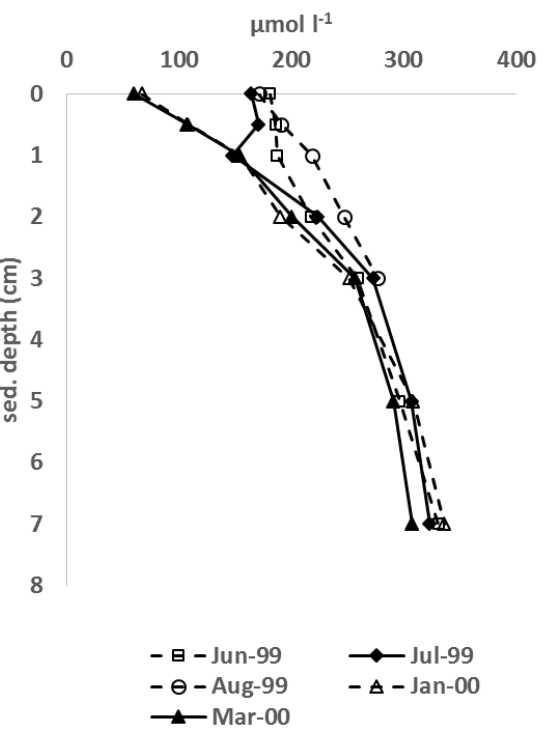

D. Ahvenkoskenlahti

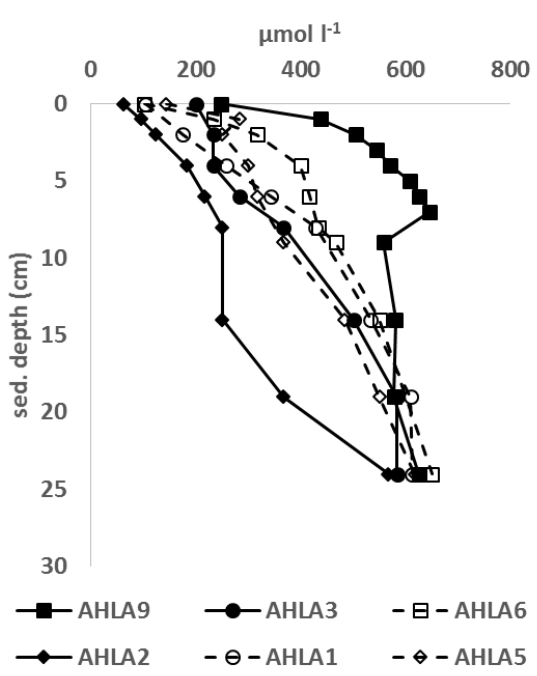

Fig. 2. The concentration ( $\mu \mathrm{mol} \mathrm{l}^{-1}$ ) of DSi in the pore water sediment profiles at the studied stations. Note that in A-B, the different profiles denote different sampling times, whereas in C-D the profiles are from different stations. In D. (Ahvenkoskenlahti) both the vertical and horizontal scales are, also, different. 
The concentrations of DSi in the pore water in the estuarine Ahvenkoskenlahti (the AHLA stations) were higher than elsewhere (Fig. 2, note the different scales). In the inner and open coastal areas there was some, but quite slight, seasonal variation, as the values were higher in summer than in winter at Storfjärden and Storgadden. The highest surface concentration was measured at Storgadden $\left(180 \mu \mathrm{mol} \mathrm{1^{-1 }}\right)$ in June. At Storgadden, the shape of the pore water profile differed from the rest in summer (June, July and August, Fig. 2) with high surface values, and in AHLA 9 at Ahvenkoskenlahti the concentration peaked at $\mathrm{ca} 8 \mathrm{~cm}$ depth with declining values deeper down. The pore water concentrations obtained with the aid of Rhizon filters from Storfjärden were in the same range as the other values or slightly higher (measurements from top $3 \mathrm{~cm}$ only; all data not shown).

The concentrations of biogenic or amorphous silica (ASi) in the surface $(0-15 \mathrm{~cm})$ sediment in the southern part of the Gulf varied between 0.5 and $2 \mathrm{mmol} \mathrm{g}^{-1} \mathrm{DM}$ (as Si; Fig 3). The lowest concentrations were measured from stations V39 and V45 outside the Estonian coast, where the ASi content of the whole profile was lower than at the other stations (average 0.6 mmol g $\left.{ }^{-1} \mathrm{DM}\right)$. High concentrations were found below $8 \mathrm{~cm}$ depth at several of the stations, with the highest at stations V23 and V11, 1.8-2.0 $\mathrm{mmol} \mathrm{g}^{-1} \mathrm{DM}$. The highest average concentration was found at station V23, $1.4 \mathrm{mmol} \mathrm{g}^{-1} \mathrm{DM}$. The ASi content fluctuated vertically in most of the sediment profiles, although the variability was smaller at the stations where the concentrations were lower (Fig. 3). Most profiles also exhibited a minimum in the surface layer and a small peak at 1-2 cm depth. At Storfjärden, the ASi concentration in the sediment surface layer $(0-1 \mathrm{~cm})$ was $1.1 \mathrm{mmol} \mathrm{g}{ }^{-1} \mathrm{DM}$ (spring) and $1.4 \mathrm{mmol} \mathrm{g}^{-1} \mathrm{DM}$ (autumn).

\subsection{Benthic fluxes}

The benthic fluxes of DSi measured in vitro varied substantially both spatially and temporally (Table 1) with an overall average of $1.1 \mathrm{mmol} \mathrm{m}^{-2} \mathrm{~d}^{-1}$. At Storfjärden and Storgadden, where the seasonal variability was estimated, the flux varied between a negative value of $-0.4 \mathrm{mmol}$ $\mathrm{m}^{-2} \mathrm{~d}^{-1}$, i.e. influx into the sediment, at Storfjärden in April and a maximal value of $1.5 \mathrm{mmol}$ $\mathrm{m}^{-2} \mathrm{~d}^{-1}$ (Storfjärden, July); the average flux was somewhat lower at Storfjärden $\left(0.6 \mathrm{mmol} \mathrm{m}{ }^{-2}\right.$ $\mathrm{d}^{-1}$ due to the negative value in April), where the variability was higher, than at Storgadden (average $1.5 \mathrm{mmol} \mathrm{m}^{-2} \mathrm{~d}^{-1}$, Fig. 4). The highest fluxes were measured in July-August and the 
lowest in March-April. In the open Gulf of Finland, the highest fluxes were measured at stations V39 and V10 in the southern part of the Gulf outside the Estonian coast (1.2 and 1.4 mmol m $\mathrm{m}^{-2}$, Table 1), i.e. values of similar magnitude as those measured at Storfjärden and Storgadden at the same time in the seasonal cycle in August (Fig. 4).

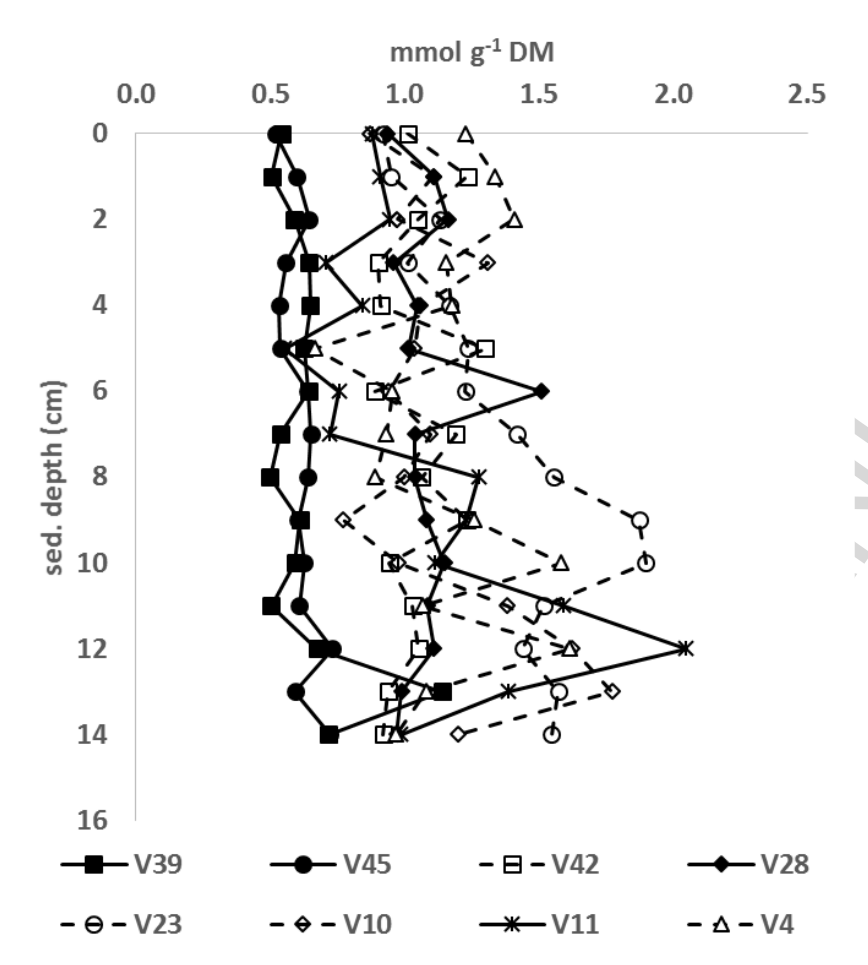

Fig. 3. The concentration ( $\mathrm{mmol} \mathrm{g}^{-1}$ dry mass, DM) of ASi in the sediment profiles from the Southern Gulf of Finland.

The variability was, however, high, with negative or very low values also found at coastal stations in the North-Eastern part of the Gulf $\left(-1.1\right.$ to $\left.0.02 \mathrm{mmol} \mathrm{m}^{-2} \mathrm{~d}^{-1}\right)$. The highest Si fluxes measured in this study were from Ahvenkoskenlahti Bay, where the average flux was $2.7 \mathrm{mmol} \mathrm{m} \mathrm{d}^{-1}$; in the semi-enclosed Sandöfjärden, however, the Si fluxes were low or moderate (-0.1 to $\left.0.6 \mathrm{mmol} \mathrm{m}^{-2} \mathrm{~d}^{-1}\right)$, resembling those measured from the Eastern coastal stations. 


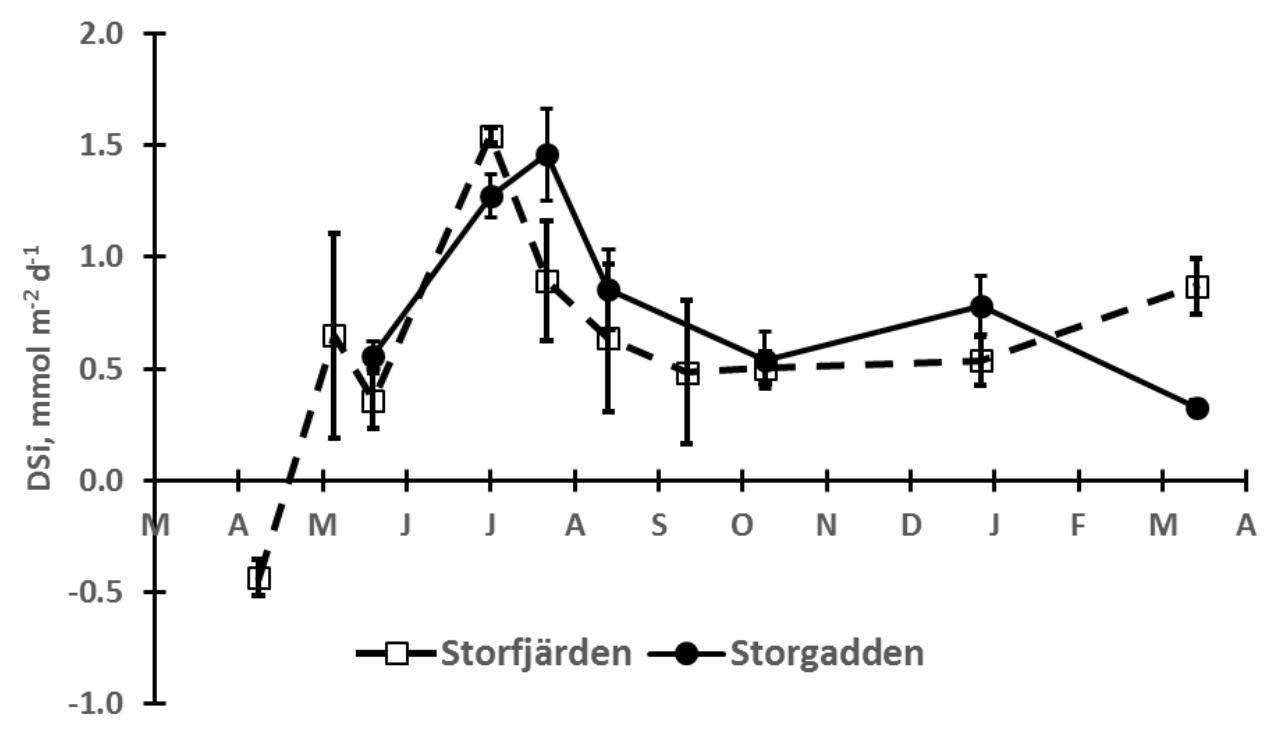

Fig. 4. The temporal variability in the sediment-water fluxes of DSi $\left(\mathrm{mmol} \mathrm{m} \mathrm{d}^{-1}\right)$ measured from Storfjärden and Storgadden (northern Gulf of Finland) during one seasonal cycle.

The benthic fluxes of DSi measured in situ at Storfjärden in 2014 with the aid of the benthic lander were higher than the in vitro measurements, $1.9-3.3 \mathrm{mmol} \mathrm{m}^{-2} \mathrm{~d}^{-1}$ (Table 1); it should be noted that the lander measurements were made at shallower sites of 7 and $20 \mathrm{~m}$ depth, however. The highest values were measured at the shallower $7 \mathrm{~m}$ site.

The fluxes estimated using diffusion calculations based on the gradient between measured bottom-water and top sediment pore water DSi concentrations ranged from 0.2 to $0.3 \mathrm{mmol}$ $\mathrm{m}^{-2} \mathrm{~d}^{-1}$ and constituted ca $20 \%$ of the respective measured fluxes (all data not shown, averages in Table 1). When diffusive benthic fluxes were estimated from the concentration gradient at the sediment surface calculated from pore water DSi gradients using regression equations, the fluxes were often even lower, but in general in the same range (all data not shown, averages in Table 1). 


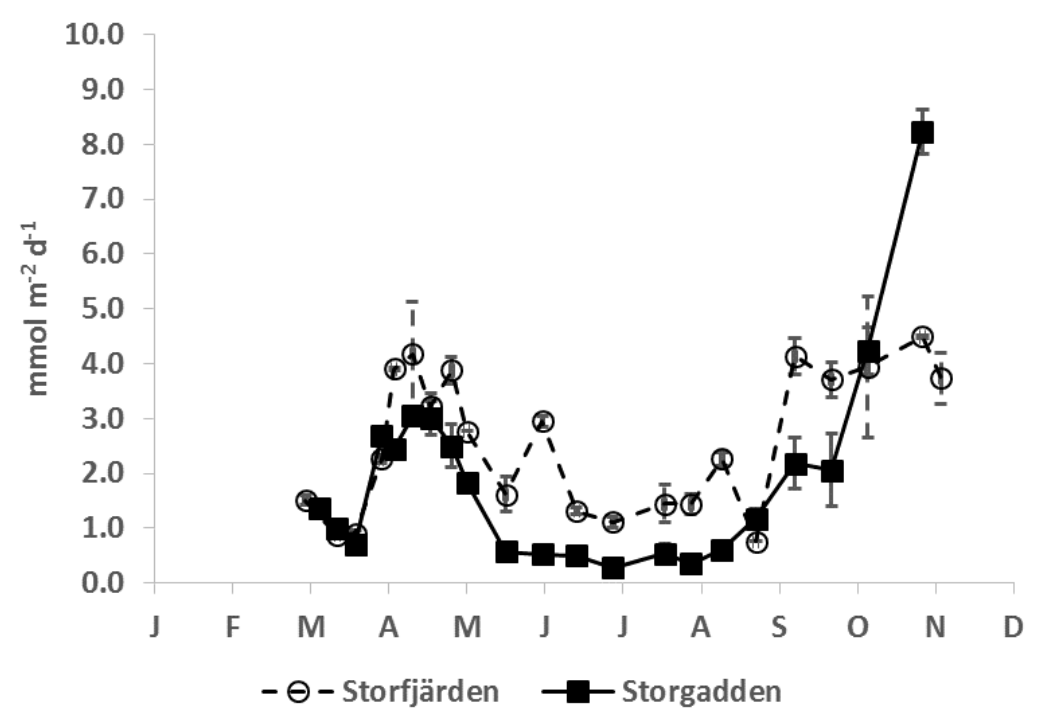

Fig. 5. The sedimentation flux of ASi $\left(\mathrm{mmol} \mathrm{m}^{-2} \mathrm{~d}^{-1}\right)$ measured with the aid of sedimentation traps at $20 \mathrm{~m}$ depth in the water column at Storfjärden and Storgadden during one seasonal cycle.

\subsection{ASi sedimentation fluxes}

The sedimentation of ASi was highest in late autumn at both Storfjärden and Storgadden, where the maximal value $\left(8 \mathrm{mmol} \mathrm{m} \mathrm{m}^{-2}\right)$ was measured in November (Fig. 5). Peaks in sedimentation also occurred in May (3-4 mmol m $\mathrm{m}^{-2}$ ) while it was lowest in late summer (0.3-1.6 mmol m $\left.\mathrm{m}^{-2} \mathrm{~d}^{-1}\right)$. With the exception of the high value in November, the sedimentation of ASi was lower at Storgadden (average $1.9 \mathrm{mmol} \mathrm{m}^{-2} \mathrm{~d}^{-1}$ ) than at Storfjärden (average 2.6 mmol m $\mathrm{m}^{-2} \mathrm{~d}^{-1}$ ). The sedimentation of ASi correlated well with that of total particulate matter (TPM) at Storgadden $(r=0.82, \mathrm{p}<0.001)$ but less so at Storfjärden $(r=0.37, p<0.001$; TPM data from Heiskanen \& Tallberg 1999). The sedimentation of ASi made up between 0.5 and $3 \%$ of the sedimentation of TPM, with the highest proportion in April-May at the time of the spring bloom.

\subsection{Loading and stocks}

The main part, almost $80 \%$, of the load of DSi to the Gulf of Finland $\left(2.6 \mathrm{Gmol} \mathrm{a}^{-1}\right)$ is brought by the three largest rivers discharging into the Gulf, i.e. Neva, Narva and Kymijoki; data previously published by Humborg et al. (2008). Despite the low concentration of DSi in the water from Neva $\left(8 \mu \mathrm{mol} \mathrm{l}^{-1}\right)$, the high discharge of the river thus makes the load 
significant. The load from the smaller rivers, e.g. Mustijoki and Taasianjoki, correspondingly remains relatively insignificant despite the much higher average concentrations of DSi in the river water $\left(350-450 \mu \mathrm{mol} \mathrm{l}^{-1}\right)$.

Table 2. The stock of DSi in the Gulf of Finland calculated from available monitoring data based on the average concentration of DSi in the water column, the depth at each station and the area of the Gulf of Finland (see text for details).

\begin{tabular}{|c|c|c|c|c|c|c|c|}
\hline & $\mathrm{D}_{\max }$ & $\mathrm{n}$ & Time period & Average & $\begin{array}{l}\text { Average } \\
\text { surface } \\
\text { water }\end{array}$ & $\begin{array}{l}\text { Average } \\
\text { bottom } \\
\text { water }\end{array}$ & Average \\
\hline & $\mathrm{m}$ & & & $\mu \mathrm{mol} \mathrm{l}^{-1} \mathrm{~S}$ & $\mu \mathrm{mol} \mathrm{l}^{-1} \mathrm{Si}$ & $\mu \mathrm{mol} \mathrm{l}^{-1} \mathrm{Si}$ & $\mathrm{Gmol} \mathrm{a}^{-1}$ \\
\hline Average & 43 & 28675 & $1958-2013$ & 14 & 13 & 20 & 15 \\
\hline Max & 90 & & & 57 & 48 & 58 & 63 \\
\hline Min & 8.5 & & & 0.9 & 1.2 & 4.2 & 2.3 \\
\hline
\end{tabular}

The DSi concentration in the water column in the coastal Gulf of Finland varied relatively little on a spatial scale, with an average concentration of $14 \mu \mathrm{mol} \mathrm{l}^{-1}$ (entire water column)

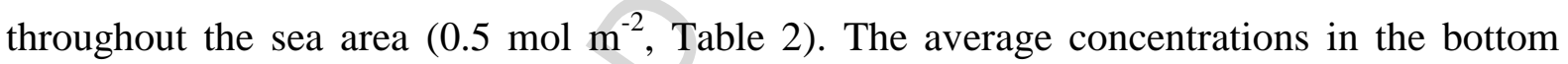
waters were higher $\left(20 \mu \mathrm{mol} \mathrm{1^{-1 }}\right)$ than in the surface waters $\left(13 \mu \mathrm{mol} \mathrm{l^{-1 }}\right)$, except in nearshore, shallow areas, where the opposite was true. The highest values were measured in winter (Nov-Mar) and the lowest in spring (Apr-June). The largest differences between surface and bottom water concentrations generally occurred at the deepest stations. The total stock of DSi in the water of the Gulf of Finland was estimated to be ca 15 Gmol (Table 2, Fig. 6).

Table 3. Correlation coefficients (Pearson) between ASi concentrations in sediment, DSi sediment-water flux and bottom-water oxygen concentrations at those of the studied stations where these measurements were available $(n=9)$.

\begin{tabular}{lrrrc} 
& ASi & DSi flux & Depth & Bottom-water $\mathrm{O}_{2}$ \\
\hline ASi & 1.00 & & & \\
DSi flux & -0.75 & 1.00 & & \\
Depth & 0.38 & -0.64 & 1.00 & \\
Bottom-water $\mathrm{O}_{2}$ & -0.02 & 0.34 & -0.65 & 1.00
\end{tabular}




\subsection{Correlations between DSi and ASi}

When the average values for ASi concentration in the sediment surface layer and sedimentwater flux of DSi ( $n=10$, Ahvenkoskenlahti ASi data from Tallberg et al. 2012) were compared to each other, the ASi concentrations and DSi fluxes were negatively correlated (Pearson, $r=-0.75$; Table 3), although the correlation was not statistically significant (p>0.01, t-test).

\subsection{Si budget}

The loading of Si into the Gulf of Finland consisted of $2.6 \mathrm{Gmol} \mathrm{a}^{-1}$ of DSi brought by rivers, an estimated $2.0 \mathrm{Gmol} \mathrm{a}^{-1}$ ASi likewise brought by rivers (cf. Lehtimäki et al. 2013), and of the net exchange of DSi with the Baltic Proper. This is, according to Papush et al. (2009), positive and brings $3.8 \mathrm{Gmol} \mathrm{a}^{-1}$ of DSi into the Gulf yearly (Fig. 6). The output consisted of the amount of ASi buried in the sediment yearly. Here, we used two estimates, i.e. either 18 $\mathrm{Gmol} \mathrm{a}^{-1}$ (burial in the sediments of the whole Gulf, $30000 \mathrm{~km}^{2}$, Fig. 6A) or $6.2 \mathrm{Gmol} \mathrm{a}^{-1}$ (burial in the estimated accumulation area, $10500 \mathrm{~km}^{2}$, only, Fig. 6B).

When all the measured benthic flux values were used to estimate the yearly benthic flux of (D)Si from the sediments in the entire Gulf of Finland, the average flux amounted to $14 \mathrm{Gmol}$ $\mathrm{a}^{-1}\left(290 \mathrm{kt} \mathrm{Si} \mathrm{a}^{-1}\right)$. If the sedimentation fluxes were, likewise, extrapolated to the whole Gulf of Finland, a total of $24 \mathrm{Gmol} \mathrm{a}^{-1}\left(690 \mathrm{kt} \mathrm{a}^{-1}\right)$ of ASi would reach the sediment yearly (Fig. 6A). If, however, only the accumulation area of the Gulf was used in the calculations, the benthic flux of DSi would amount to $4.9 \mathrm{Gmol} \mathrm{a}^{-1}$ and the sedimentation of ASi to $8.6 \mathrm{Gmol}$ $\mathrm{a}^{-1}$ (Fig. 6B).

\section{Discussion}

\subsection{Benthic fluxes of DSi in the Gulf of Finland}

\subsubsection{Comparisons to reported fluxes \& methodological considerations}

The relatively few published benthic fluxes of Si measured in the Gulf of Finland have in general been of the same magnitude as those measured here. The fluxes measured by Conley \& Johnstone (1995) from unmanipulated sediment cores from the open Gulf were approximatively $0.7 \mathrm{mmol} \mathrm{m}^{-2} \mathrm{~d}^{-1}$, and Villnäs et al. (2013) measured Si fluxes of $0.1 \mathrm{mmol}$ 
$\mathrm{m}^{-2} \mathrm{~d}^{-1}$ from a shallow coastal sediment. The higher fluxes from the estuarine Ahvenkoskenlahti Bay (average $2.5 \mathrm{mmol} \mathrm{m}^{-2} \mathrm{~d}^{-1}$, range 0.6-5.0 $\mathrm{mmol} \mathrm{m}^{-2} \mathrm{~d}^{-1}$ ) and from the shallow sites in Storfjärden as measured with the benthic lander (1.9-3.3 $\left.\mathrm{mmol} \mathrm{m}^{-2} \mathrm{~d}^{-1}\right)$ are, on the other hand, similar to Si fluxes measured by Karlson et al. (2005) in the Stockholm archipelago (Kanholmsfjärden), 1.2-3.3 mmol m $\mathrm{m}^{-2} \mathrm{~d}^{-1}$, and by Norkko et al. (2015) in the Northern Gulf, up to 3-4 mmol m $\mathrm{m}^{-2} \mathrm{~d}^{-1}$. The numbers are not, however, as high as the highest values measured by Ekeroth et al. (2016a) from a 149 m deep site in the NW Baltic Proper (up to $15 \mathrm{mmol} \mathrm{m}^{-2} \mathrm{~d}^{-1}$ ). The similarity between the measured values is encouraging from a methodological point of view, as there was plenty of variety in the measurement techniques and calculations, ranging from in vitro incubations of sampled sediment cores (here, Conley \& Johnstone 1995, Norkko et al. 2015) to lander measurements (here, Ekeroth et al. 2016a,b) and benthic chambers (Villnäs et al. 2013).

The benthic fluxes in the shallow Ahvenkoskenlahti Bay and at the shallow stations in Storfjärden (measured by the benthic lander) were high, especially compared to the other measurements from Storfjärden. The high fluxes in Ahvenkoskenlahti Bay may have been a function of the extreme shallowness of the bay (high temperature) in combination with the high inflow of material with high potential for dissolution from the Kymijoki River. The higher fluxes at the shallow stations in Storfjärden may have been partly due to the different measurement technique: it has been shown that core incubations generally produce lower (DSi) fluxes than benthic in situ incubations (see Viktorsson et al. 2012) and that the difference is primarily due to changes in faunal activity (Hammond et al. 2004). Differences in faunal composition between the shallower and deeper sites is another possible reason for the higher DSi fluxes in the shallow areas; the pore water concentrations and consequently diffusive fluxes were similar at the shallow and deeper stations in Storfjärden. 

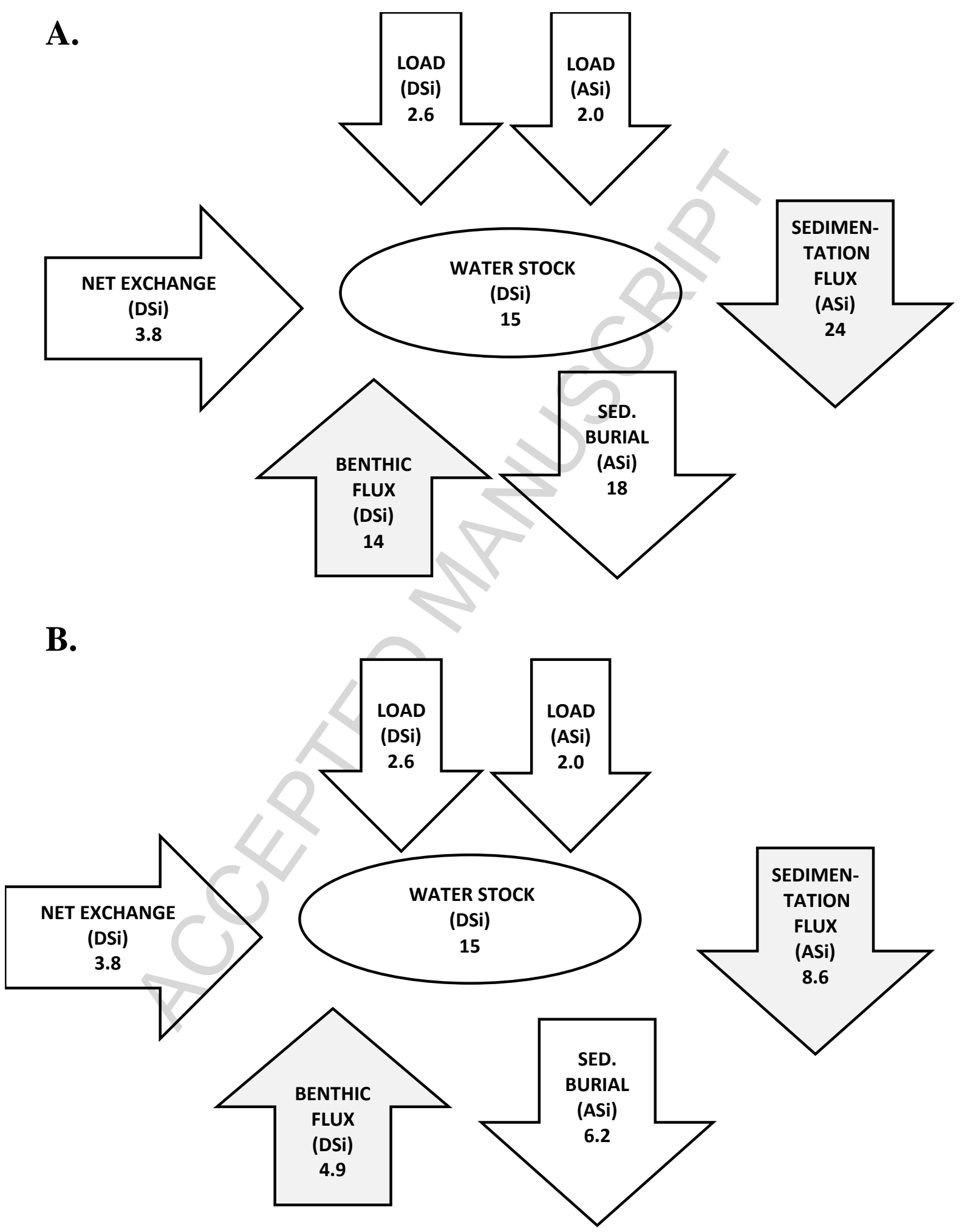

Fig. 6. A schematic presentation of the budget flows of $\mathrm{Si}$ in the Gulf of Finland in Gmol $\mathrm{a}^{-1}$.

The shaded arrows represent internal cycling of Si. In A., the burial, sedimentation flux and benthic flux of Si was calculated using the entire Gulf of Finland sediment area and in B. using the accumulation area only. 
Fluxes based on diffusion calculations (cf. Märtz et al. 2015), i.e. on the concentration gradient of DSi at the sediment-water interface, have not been published from the studied area, but those calculated here ranged between 0.2 and $0.3 \mathrm{mmol} \mathrm{m}^{-2} \mathrm{~d}^{-1}$, i.e. only maximally ca $20 \%$ of the measured ones. Discrepancies between calculated diffusive and measured fluxes are commonly observed (Conley \& Schelske 1989, Barbanti et al., 1992; Srithongouthai et al. 2001, Berelson et al. 2015), although not always found (Ragueneau et al. 2001); benthic chamber and incubated core sediment fluxes may also differ significantly from each other (Hammond et al. 2004). A ratio of 3.2 for incubated:diffusive flux has even been proposed (Srithongouthai et al. 2001), i.e. somewhat lower than here, where some values were extremely high due to the very low calculated diffusive fluxes. The differences between measured and calculated fluxes is postulated to be due to physical and bioturbation processes, which are not taken into account by diffusive calculations (e.g. Barbanti et al. 1992). Based on our data, diffusion calculations at the fairly rough resolution possible when sediment is sampled at a scale of $0.5-1 \mathrm{~cm}$ (as here) do not give a realistic picture of actual fluxes, and our diffusive fluxes can be regarded mainly as theoretical minimum values.

\subsubsection{Differences in DSi fluxes due to ASi accumulation patterns and oxygen concentrations}

Fairly high fluxes were also measured from stations situated in the main Gulf of Finland basin below the halocline (which, on average, is situated at 60-80 m depth, Alenius et al. 1998). High Si effluxes in the area beneath the halocline could be explained by lower oxygen concentrations in the bottom water, as such conditions have been tentatively shown to affect benthic Si fluxes positively in the Baltic Sea (e.g. Tallberg et al. 2009, 2012, Danielsson 2014, Bonaglia et al. 2013, Ekeroth et al. 2016a,b) for reasons which at present are not very clear (but see e.g. Mortimer 1941,1942, Ekeroth et al. 2016a,b, Siipola et al. 2016). The fact that the fluxes, not only measured concentrations in the bottom water, appear to be high in commonly hypoxic or anoxic areas indicate that the redox conditions themselves influence the benthic DSi flux. Danielsson (2014) proposed that stagnation of the bottom waters during prolonged periods of anoxia would be the main reason for the higher concentrations, as DSi released from the sediment simply accumulates in the stagnant bottom water, but this may thus have to be reconsidered (see also Bonaglia et al. 2013 and Ekeroth et al. 2016a,b). Some inconclusive support for direct redox-influence is shown by the high surface concentrations of DSi in the pore water profiles at Storgadden in summer $\left(>160 \mu \mathrm{mol} \mathrm{l}^{-1}\right.$ in June-August, 
Fig. 2). Stagnant water with or without the presence of oxygen may of course also affect the diffusive release of DSi from the sediment by modifying the thickness of the diffusive boundary layer and thus the concentration gradient at the sediment-water interface, but this should eventually lead to lower, not higher release from the sediment, as the concentration gradient levels out. Changes in the abundance and composition of benthic fauna and bioturbation when oxygen concentrations decline or oscillate may be another significant factor, as the connection between benthic (animal) activity and DSi efflux has been shown to be strong (e.g. Aller 1980, Rutgers van der Loeff et al. 1984, Bonaglia et al. 2013).

There was not any clear regional pattern in the benthic flux measurements, although the values measured in the southern pelagial part of the Gulf along the Estonian coast were on average higher than in the northern part, and the lowest values were found in the northeastern part of the Gulf. An inverse relationship between the concentration of ASi and the efflux of DSi from the sediment appeared (additional ASi concentrations from Tallberg et al. 2012), i.e. a high efflux of DSi was generally accompanied by lower ASi concentrations in the top sediment. Ahvenkoskenlahti Bay, where the efflux of DSi was high, thus had relatively low concentrations of ASi in the sediment, while the stations with low efflux of DSi had higher ASi concentrations (e.g. Storfjärden). Without the samples from Ahvenkoskenlahti, the relationship was weaker but still negative. It may be that the relationship is spurious, as the sampled stations in Ahvenkoskenlahti Bay were very shallow (4-13 m) compared to most of the others (53-89 $\mathrm{m}$ with the exception of Storfjärden, $35 \mathrm{~m}$ ) from which ASi data were available. On the other hand, a high efflux of DSi should indeed lead to lower accumulation of ASi in the sediment, as ASi is generally the pool that can be considered dissolvable at relevant, non-geological time scales (e.g. Hurd 1983).

\subsubsection{Seasonal differences in benthic DSi fluxes}

Seasonally, there was a clear peak in the fluxes in late summer (July-August, $>1 \mathrm{mmol} \mathrm{m}^{-2} \mathrm{~d}^{-}$ ${ }^{1}$ ) with relatively small variation otherwise, except for the negative fluxes measured at Storfjärden in April (-0.4 mmol m $\mathrm{m}^{-2} \mathrm{~d}^{-1}$ ). These negative values may have been caused by dark uptake of still viable diatoms which had settled out of the water column at the end of the spring bloom; uptake of DSi by diatoms is not limited by darkness, as the energetics of the process is more closely coupled to respiration than photosynthesis (reviewed by MartinJézéquel et al. 2000). The higher efflux of Si in mid-late summer will have been caused by 
the eventual dissolution of a large part of the same, settled diatoms, as it has been previously shown (in vitro) that the dissolution of spring bloom diatom material in a sediment environment increases for the first 60 days after addition, evening out thereafter, when most of the labile (A)Si has been dissolved (Tallberg et al. 2013). Seasonal variability may thus cause annual fluxes to be either over- or underestimated if flux measurements are performed either in summer at the time of the peak values or very early in spring; if single measurements are used, the autumn values are closest to the yearly averages, based on the two seasonally studied stations. The high DSi effluxes measured by Norkko et al. (2015) were, for instance, sampled during early summer, when DSi effluxes tend to peak.

In summary, the DSi benthic flux values obtained by direct flux measurements and benthic landers were several times higher than the estimates from diffusion calculations, and there appeared to be a negative relationship between DSi sediment-water fluxes and ASi concentration in the sediment. Although there was some spatial variation, the variability in the fluxes in the open Gulf of Finland was relatively small. In the shallow areas, both very high and very low fluxes were measured. DSi sediment-water fluxes in the Gulf of Finland were highest in late summer and lowest in early spring, and followed the same pattern as the release of dissolved phosphate (Lehtoranta \& Heiskanen 2003).

\subsection{Silicon fluxes and stocks in the Gulf of Finland: a revisited budget with implications}

A simplistic box model approach produces the Si budgets for the Gulf of Finland pictured in Fig. 6. There are a number of suppositions involved in the budget, which depicts the shortterm fluxes of potentially bioavailable $\mathrm{Si}$ pools, i.e. DSi and $\mathrm{Na}_{2} \mathrm{CO}_{3}$-extractable amorphous or biogenic Si (here termed ASi for simplicity's sake). The authors acknowledge that, despite the mineral correction applied in the analysis, what is extracted by $\mathrm{Na}_{2} \mathrm{CO}_{3}$ is not necessarily only $\mathrm{Si}$ of biogenic origin but a complex mixture of biogenic, amorphous mineral and easily desorbed Si pools (see e.g. Barão et al. 2015). For the purposes of the budget, it is not essential to distinguish between these pools, as we are primarily interested in the amount of Si that is or may become bioavailable at short-term timescales and not as much in its origin. We are, of course, aware that we extrapolate our numbers into a very complex natural environment based on a relatively limited number of samples and measurements, and that the data on which the budget is based varies in its spatial and temporal coverage. Despite these 
shortcomings we present, however, a rare combination of measurements and monitoring data with fair areal coverage.

The main novelty of our budget is that we include data on the benthic flux of DSi, which according to our calculations are significant in the cycling of bioavailable $\mathrm{Si}$ on annual to decadal time-scales in the Gulf. We also relate the fluxes of DSi to estimates of the amount of ASi that is brought into the Gulf by rivers and to the sedimentation of ASi. The loading of ASi is one factor which should be taken into account when Si budgets are calculated, but on which there is very little data available, while data on sedimentation of ASi helps us to understand the internal processes that affect the burial and release of Si from the sediment.

For the purposes of this budget, we assume that the Si budget for the Gulf of Finland is in a steady state, i.e. that the stock of (D)Si in the water column remains fairly constant on a yearly to decadal scale - a declining trend in the DSi concentration in the Baltic Sea has been shown to have leveled out over recent decades (Papush \& Danielsson 2006). As there is no comprehensive data available on the loading of ASi via rivers into the Baltic Sea, we also assume that the data of Lehtimäki et al. (2013), who studied the loading of ASi into the Gulf of Finland via one river (Vantaanjoki), can be tentatively extrapolated to the rest of the Gulf of Finland in the absence of better data. Lehtimäki et al. (2013) found that the yearly load of ASi was of the same magnitude or slightly lower than the load of DSi brought by that particular river. If we extrapolate this to the rest of the rivers flowing into the Gulf, the load of potentially bioavailable Si received increases to ca $9 \mathrm{Gmol} \mathrm{a}^{-1}$. As the loading of ASi from the catchment is still quite poorly constrained (globally as well, cf. Treguer \& DelaRocha 2013), it is possible that either more or less ASi is brought into the Gulf of Finland than our current estimate suggests. The amount is however not likely to differ a great deal, unless the largest rivers draining into the Gulf (Neva, Narva, Kymijoki) differ markedly in the proportion of ASi to DSi compared to Vantaanjoki. The net inflow into the Gulf of Finland from the Baltic Proper (Papush et al. 2009) is based on water exchange modelling using salinity as a conservative tracer (and DSi monitoring data) and was shown by these authors to follow other modelling efforts concerning water movements in the Baltic (e.g. Savchuk 2005, Meier 2007) quite well.

The higher ASi burial estimate in our study $\left(18 \mathrm{Gmol} \mathrm{a}^{-1}\right)$ is very close to the estimate produced by using the ASi and sediment accumulation rate data from Tallberg et al. (2012), 
$19 \mathrm{Gmol} \mathrm{a}^{-1}$, and also similar to the BSi burial for the whole Baltic Sea (1074 kt a ${ }^{-1}$ as $\mathrm{SiO}_{2}$, i.e. ca $18 \mathrm{Gmol} \mathrm{a}^{-1}$ as $\mathrm{Si}$ ) estimated by Conley et al. (2008). It is, however, very likely that all these values are overestimated. In their Baltic Sea Si budget, Papush et al. (2009) propose that one reason for the high burial estimates is that sediment accumulation rates are overestimated. This may however be a bigger problem in other parts of the Baltic, i.e. the Bothnian Bay and Sea, than in the Gulf of Finland, as there is a fair amount of published sedimentation rates available from the Gulf of Finland ( $n=53$, Mattila et al. 2006). As we do not have sedimentation rate measurements for the exact sites from where the ASi data in this study comes from and thus used the median value of $690 \mathrm{~g} \mathrm{~m}^{-2} \mathrm{a}^{-1}$ (Mattila et al. 2006) in our $\mathrm{Si}$ burial calculations, there is certainly an additional source of error included there, particularly as the variability in measured sedimentation rates was high (from ca 140 to almost $3000 \mathrm{~g} \mathrm{~m}^{-2} \mathrm{a}^{-1}$; Mattila et al. 2006).

A more likely source of error is, however, that the use of the entire surface sediment area of the Gulf of Finland in the burial calculations produces too high burial estimates. If Si burial is calculated using only the estimated accumulation area (ca 1/3 of the entire area), the estimate of $6.2 \mathrm{Gmol} \mathrm{a}^{-1}$ is closer to that produced by the model used in Papush et al. (2009), 7.1 Gmol $\mathrm{a}^{-1}\left(199 \mathrm{kt} \mathrm{a}^{-1}\right)$, and the budget far less unbalanced. If we use the lower burial estimate, we are actually faced with a budget where more $\mathrm{Si}\left(\mathrm{ca} 2 \mathrm{Gmol} \mathrm{a}^{-1}\right.$ ) is brought into the Gulf than what is buried in the sediment (i.e. opposite to what has earlier been shown, cf. Conley et al. 2008, Papush et al. 2009). If we look at what is new in our budget, i.e. the internal cycling of Si within the Gulf, it is also clear that a lower burial estimate is reasonable. If we use the whole area of the Gulf of Finland when calculating the annual benthic flux of DSi (14 Gmol a $\left.{ }^{-1}\right)$ and the sedimentation flux of ASi $\left(24 \mathrm{Gmol} \mathrm{a}^{-1}\right)$, ca $10 \mathrm{Gmol} \mathrm{a}^{-1}$ of ASi is left for (semi)permanent burial in the sediment, i.e. significantly less than the higher ASi burial estimate presented above $\left(18 \mathrm{Gmol} \mathrm{a}^{-1}\right)$ and closer to the lower one $\left(6.2 \mathrm{Gmol} \mathrm{a}^{-1}\right)$. Scaling up the sedimentation flux of ASi very likely over-estimates the total sedimentation, as we only have data from two stations of 30 respectively $60 \mathrm{~m}$ depth. By using only the accumulation area of the Gulf to calculate the annual sedimentation flux of ASi and the annual benthic flux of DSi, the sedimentation of ASi diminishes to $8.6 \mathrm{Gmol} \mathrm{a}^{-1}$ and the benthic flux of DSi to $4.9 \mathrm{Gmol}$ $\mathrm{a}^{-1}$. This leaves us with an even smaller internally estimated value for semi-permanent burial, 3.7 $\mathrm{Gmol} \mathrm{a}^{-1}$, supporting the lower burial estimate of $6.2 \mathrm{Gmol} \mathrm{a}^{-1}$ further. 
There are, of course, additional caveats when Si burial is estimated. What we consider as buried $\mathrm{ASi}$ are the $\mathrm{Si}$ pools extracted by $1 \% \mathrm{Na}_{2} \mathrm{CO}_{3}$ at $80^{\circ} \mathrm{C}$ after a correction for mineral interference (cf. DeMaster 1981). This may be a fairly correct estimate for the amount of Si that is potentially bioavailable, but whether this correctly represents biogenic Si recently deposited into the sediment from the water column remains obscure. Diagenetic and reverse weathering reactions continuously modify the particulate material present, and some of these processes may be surprisingly quick (e.g. Michalopolous \& Aller 2004, Loucaides et al. 2012): some ASi of biogenic origin may "disappear" out of reach of the analysis. It may thus be that the ASi concentration measured from the sediment is lower than that actually derived from the water column, lowering the burial estimate. The size of the accumulation area is, of course, also only an estimate, and it is eminently possible that burial takes place in a larger area. It is also possible that our supposition about the steady state of the system is at fault, as it has been proposed that the pool of $\mathrm{Si}$ in the water column of the Gulf of Finland is currently increasing (Oleg Savchuk, unpublished information). Several possible sinks for the "extra" Gmols of Si brought into the Gulf of Finland yearly in our lower burial budget thus exist.

Our budget illustrates the importance of internal recycling of Si within the ecosystem, as it shows that more than half of the annual sedimentation flux of ASi is released back into the water column as DSi. The production of siliceous phytoplankton is thus dependent on the functioning of this internal recycling pump, and changes in the release of DSi from the sediment may have large impacts on the functioning of the food web. Although the proportion of dinoflagellates in the spring bloom has increased at the expense of diatoms in the Gulf of Finland (Klais et al. 2011), there are no clear signs of DSi limitation being an important factor in this context (cf. Spilling 2007, Spilling et al. 2010). It has rather been proposed that the reason behind the increases in dinoflagellate biomass at the expense of diatoms have to do with timing and seed bank efficiency in the shallow coastal waters (Spilling et al. 2010, Klais et al. 2011). As the benthic flux of DSi exhibits a clear seasonal trend, with peak efflux in summer and lower values throughout the period before the spring bloom, disturbances in this seasonal pattern, past or future, may, however, alter the competitiveness of diatoms through changes in the supply of DSi over time.

The $20^{\text {th }}$ century eutrophication of the Baltic Sea and the lakes in its catchment was probably one of the factors behind the observed decrease in DSi concentrations in the water mass of 
the Baltic in the late 1900s and early 2000s, as it increased sedimentation losses of Si (Rahm et al. 1996). Despite the continually eutrophic state of the Gulf of Finland (cf. Andersen et al. 2015), there are currently, however, rather signs of an increase in the stock of Si. This phenomenon may have multiple causes. The lowered frequency of changes in the catchment (e.g. no new dams, less drastic land-use changes, Humborg et al. 2002, 2006, 2008) and the possible amelioration of the water quality in other parts of the Baltic (Andersen et al. 2015) may, e.g., have contributed. Another possible factor is, however, the large hypoxic bottom area in the Baltic Sea (up to $80000 \mathrm{~km}^{2}$; Conley et al. 2009, Carstensen et al. 2014). Our data tentatively show that the release of DSi from the sediment is higher under low oxygen conditions, and that earlier observed higher DSi concentrations in stagnant bottom waters, cf. Danielsson 2014, are not necessarily due to the stagnation itself (see also Spilling \& Lindström 2008, Ekeroth et al. 2016a,b, Siipola et al. 2016). Larger hypoxic areas could thus potentially compensate for lowered DSi inputs from elsewhere and/or accelerate the recycling of eutrophication-induced higher sedimentation of ASi.

\section{Conclusions}

In a revised short-term Si budget for the Baltic Sea, we present a scenario where the burial of $\mathrm{Si}$ in the Gulf of Finland is estimated from measured sedimentation fluxes of ASi and the benthic flux of DSi. We also propose that the loading of DSi $\left(2.6 \mathrm{Gmol} \mathrm{a}^{-1}\right)$ is accompanied by a load of ASi of similar magnitude ( $2 \mathrm{Gmol} \mathrm{a}^{-1}$, extrapolated from Lehtimäki et al. 2013) and that calculating Si burial from the concentration of ASi in the top sediment layer and the area of the entire Gulf of Finland produces too high estimates $\left(18 \mathrm{Gmol} \mathrm{a}^{-1}\right)$. While spuriously high sediment accumulation rates (cf. Mattila et al. 2006, Papush et al. 2009) and problems inherent in the mineral correction rate applied in the ASi analysis (Barão et al. 2015) may contribute, the use of the estimated sediment accumulation area (ca 1/3 of the total area) produces a lower and more reasonable $\mathrm{Si}$ burial rate $\left(6.2 \mathrm{Gmol} \mathrm{a}^{-1}\right)$.

The recycling of Si within the aquatic ecosystem via the sediment, manifested as benthic flux of DSi, represents a high percentage of the, on an annual scale, bioavailable Si in the Gulf of Finland. Bioturbation and/or otherwise induced sediment mixing processes appear to be important in the sediment-water exchange processes in the Gulf, as diffusion calculations produced much lower DSi efflux estimates than flux measurements. The observed seasonal variability, with peak effluxes in summer and low or even negative fluxes in spring, is similar 
to the seasonal pattern of storage and release of dissolved phosphate. In addition, a tentative connection between hypoxia and high DSi efflux exists in the Gulf. As internal recycling plays an important part in DSi bio-availability, changes in its efficiency may affect the prevalence of siliceous phytoplankton within the ecosystem: The diatom spring bloom may be largely regulated by the functioning of this internal recycling pump. To highlight the significance of these internal functions, we need a better understanding of the processes controlling burial in and release of DSi from sediment.

\section{Acknowledgements}

We are grateful to Nils Ekeroth and Mikhail Kononets for their valuable help with the lander deployments in Tvärminne in 2014. Many thanks are also due to the staff at Tvärminne Zoological Station during the past three decades. Susanna Hietanen and Heikki Peltonen provided good and relevant comments which improved the manuscript considerably. This was supported by the Academy of Finland (grant 267112) and the BONUS COCOA project supported by BONUS (Art 185), funded jointly by the EU and the Academy of Finland.

\section{References}

Alenius P., Myrberg K. \& Nekrasov A. 1998. The physical oceanography of the Gulf of Finland: a review. Bor. Env. Res. 3, 97-125.

Aller R.C. 1980. Quantifying solute distributions in the bioturbated zone of marine sediments by defining an average microenvironment. Geochim. Cosmochim. Acta 44,1955-1965.

Almroth E., Tengberg A., Pakhomova S.V., Andersson H. \& Hall P.O.J. 2009. Effects of resuspension on benthic fluxes of oxygen, nutrients, dissolved inorganic carbon, iron and manganese in the Gulf of Finland, Baltic Sea. Cont. Shelf Res. 29, 807-818.

Andersen J.H., Carstensen J., Conley D.J., Dromph K., Fleming-Lehtinen V., Gustafsson

B.G., Josefson A.B., Norkko A., Villnäs A. \& Murray C. 2015. Long-term temporal and spatial trends in eutrophication status of the Baltic Sea. Biological Reviews (in press, DOI: $10.1111 /$ brv.12221)

Balzer W. 1984 Organic matter degradation and biogenic element cycling in a nearshore sediment (Kiel Bight). Limnol. Oceanogr. 29, 1231-1246. 
Barão L., Vandevenne F., Clymans W., Frings P., Ragueneau O., Meire P., Conley D.J., Struyf E. 2015. Alkaline-extractable silicon from land to ocean: a challenge for biogenic silicon determination. Limnol. Oceanogr. Methods 13, 329-44.

Barbanti A., Ceccherelli V.U., Frascari F., Reggiani G. \& Rosso G. 1992. Nutrient regeneration processes in bottom sediments in a Po delta lagoon (Italy) and the role of bioturbation on determining the fluxes at the sediment-water interface. Hydrobiologia $228,1-21$.

Berelson W.M., Haskell W.Z. , Prokopenko M., Knapp A.N., Hammond D.E., Rollins N. \& Capone D.G. 2015. Biogenic particle flux and benthic remineralization in the Eastern Tropical South Pacific. Deep-Sea Res. I 99, 23-34.

Bonaglia S., Bartoli M., Gunnarsson J.S., Rahm L., Raymond C., Svensson O,. Shakeri Yekta S. \& Brüchert V. 2013. Effect of reoxygenation and Marenzelleria spp. bioturbation on Baltic Sea sediment metabolism. Mar. Ecol. Prog. Ser. 482, 43-55.

Carstensen J., Gustafsson B., Andersen J.H. \& Conley D. J. 2014. Deoxygenation of the Baltic Sea during the last century. Proceedings of the National Academy of Science of the United States of America 111(15), 5628-5633.

Clavero V., Fernández J.A. \& Niell F.X., 1992. Bioturbation by Nereis sp. and its effects on the phosphate flux across the sediment-water interface in Palmones River estuary. Hydrobiologia 235: 387-392.

Conley D.J., Björck S., Bonsdorff E., Carstensen J., Destouni G., Gustafsson B.G., Hietanen S., Kortekaas M., Kuosa H, Meier H.E.M., Müller-Karulis B., Nordberg K., Norkko A., Nürnberg G., Pitkänen H., Rabalais N.N., Rosenberg R., Savchuk O.P., Slomp C.P., Voss M., Wulff F., Zillén L. 2009. Hypoxia-Related Processes in the Baltic Sea. Env. Sci. Technol. 43, 3412-3420.

Conley D.J., Humborg C., Smedberg E., Rahm L., Papush L., Danielsson A., Clarke A., Pastuszak M., Aigars J., Ciuffa D. \& Morth C. 2008. Past, present and future state of the biogeochemical Si cycle in the Baltic Sea. J. Mar. Syst. 73, 338-346

Conley D. J., \& Johnstone R. W. 1995.. Biogeochemistry of N, P and Si in Baltic Sea sediments - response to a simulated deposition of a spring diatom bloom. Mar. Ecol. Prog. Ser. 122(1-3), 265-276.

Conley D. J. \& Malone T. C. 1992. Annual cycle of dissolved silicate in Chesapeake Bay implications for the production and fate of phytoplankton biomass. Mar. Ecol. Prog. Ser.81(2), 121-128. 
Conley D. J. \& Schelske C. L. 1989. Processes controlling the benthic regeneration and sedimentary accumulation of biogenic silica in lake-michigan. Arch. Hydrobiol. 116(1), 23-43.

Conley D. J., Stockenberg A., Carman R., Johnstone R. W., Rahm L. \& Wulff F. 1997. Sediment-water nutrient fluxes in the Gulf of Finland, Baltic Sea. Est. Coast. Shelf Sci. 45(5), 591-598.

Danielsson $\AA$. 2014. Influence of hypoxia on silicate concentrations in the Baltic proper (Baltic Sea). Bor. Env. Res.19, 267-280

Danielsson Å., Papush L. \& Rahm L. 2008. Changing the Baltic Sea as a consequence of alterations in nutrient limitations. J. Mar. Syst. 73, 263-283.

DeMaster, D. 1981. The supply and accumulation of silica in the marine environment. Geochim. Cosmochim. Acta 45, 1715-1732.

Ekeroth N., Blomqvist S. \& Hall P.O.J. 2016a. Nutrient fluxes from reduced Baltic Sea sediment: effects of oxygenation and macrobenthos. Mar. Ecol. Prog. Ser. 544,73-92.

Ekeroth N, Kononets M, Walve J, Blomqvist, S. \& Hall P.O.J. 2016b. Effects of oxygen on recycling of biogenic elements from sediments of a stratified coastal Baltic Sea basin. J. Mar. Syst. 154, Part B, 206-219.

Gallinari M., Ragueneau O., Corrin L., DeMaster D.J., Treguer P. 2002. The importance of water column processes on the dissolution properties of biogenic silica in deep-sea sediments. I. Solubility. Geochim Cosmochim Acta 66, 2701-2717

Gallinari M., Ragueneau O., DeMaster D.J., Hartnett H., Rickert D. \& Thomas C. 2008. Influence of seasonal phytodetritus deposition on biogenic silica dissolution in marine sediments-Potential effects on preservation. Deep-Sea Res Part II-Top Stud Oceanogr 55, 2451-2464.

Hammond D. E., Cummins K.M., McManus J., Berelson W.M., Smith G. \& Spagnoli F. 2004. Methods for measuring benthic nutrient flux on the California margin: comparing shipboard core incubations to in situ lander results. Limnol. Oceanogr. Methods 2,146159.

Heiskanen A.-S. \& Tallberg P. 1999. Sedimentation and particulate nutrient dynamics along a coastal gradient from a fjord-like bay to the open sea. Hydrobiologia 393, 127-140.

HELCOM. 2014. Eutrophication status of the Baltic Sea 2007-2011 - a concise thematic assessment. Baltic Sea Environmental Proceedings 143, 40 pp. Electronic file available at http://www.helcom.fi/Lists/Publications/BSEP143.pdf. 
Honjo S., Managanini S.J., Krishfield R.A., Francois R.. 2008. Particulate organic carbon fluxes to the ocean interior and factors controlling the biological pump: a synthesis of global sediment trap programs since 1983. Prog. Oceanogr. 76,217-85.

Humborg, C., Blomqvist, S., Avsan, E., Bergensund, Y., Smedberg, E., Brink, J., et al. 2002. Hydrological alterations with river damming in northern Sweden: Implications for weathering and river biogeochemistry. Global Biogeochemical Cycles, 16(3), 1039.

Humborg C., Pastuszak M., Aigars J., Siegmund H., Morth C.M. \& Ittekkot V. 2006. Decreased silica land-sea fluxes through damming in the Baltic Sea catchment significance of particle trapping and hydrological alterations. Biogeochemistry 77 (2), 265-281.

Humborg C., Smedberg E., Rodriguez Medina M., \& Morth C. 2008. Changes in dissolved silicate loads to the Baltic Sea - the effects of lakes and reservoirs. J. Mar. Syst. 73(3-4), 223-235

Hurd D. 1983. Physical and chemical properties of siliceous skeletons. In Aston, S. (ed.): Silicon geochemistry and biogeochemistry. Academic Press, London. pp. 187-244.

Kankaanpää H., Vallius H., Sandman O. \& Niemistö L. 1997. Determination of recent sedimentation in the Gulf of Finland using 137 Cs. Oceanol. Acta 20, 823-836.

Karlson K. Hulth S. Ringdahl K. \& Rosenberg R. 2005. Experimental recolonisation of Baltic Sea reduced sediments: survival of benthic macrofauna and effects on nutrient cycling. Mar. Ecol. Prog. Ser. 294, 35-49

Kauppi L., Norkko A. \& Norkko J. 2015. Large-scale species invasion into a low -diversity system: spatial and temporal distribution of the invasive polychaetes Marenzelleria spp. in the Baltic Sea. Biol Invasions 17,2055-74.

Klais R., Tamminen T., Kremp A., Spilling K. \& Olli K. 2011. Decadal scale changes of dinoflagellates and diatoms in the anomalous Baltic Sea spring bloom. Plos ONE. 6: e21567.

Klais R.,Tamminen T.,Kremp A.,Spilling K.,An W., Hajdu,S. \& Olli, K. 2013. Spring phytoplankton communities shaped by interannual weather variability and dispersal limitation: Mechanisms of climate change effects on key coastal primary producers. Limnol. Oceanogr.58, 753-76

Koroleff F. 1983. In Grasshoff, K., Ehrhardt, M. \& Kremling, K. (Eds), Methods of seawater analysis. Verlag Chimie, Weinheim. 
Kremp A., Tamminen T. \& Spilling K. 2008. Dinoflagellate bloom formation in natural assemblages with diatoms: nutrient competition and growth strategies in Baltic spring phytoplankton. Aquat.Microb. Ecol. 50, 181-196.

Kuparinen J. \& Tuominen L. 2001. Eutrophication and self-purification: Counteractions forced by large-scale cycles and hydrodynamic processes. Ambio 30, 190-194.

Lehtimäki M., Siipola V. \& Tallberg P. 2013. Seasonal dynamics of amorphous silica in Vantaa River Estuary. Silicon 5, 35-51

Lehtoranta J. 2003. Dynamics of sediment phosphorus in the brackish Gulf of Finland. Monographs of the Boreal Environment Research 24, DOI http://hdl.handle.net/10138/39329.

Lehtoranta J. \& Heiskanen A-S. 2003. Dissolved iron: phosphate ratio as an indicator of phosphate release to oxic water of the inner and outer coastal Baltic Sea. -Hydrobiologia 492,69-84.

Loucaides S., Van Cappellen P., Roubeix V., Moriceau B. \& Ragueneau O. 2012. Controls on the recycling and preservation of biogenic silica from biomineralization to burial. Silicon 4,7-122.

Martin-Jézéquel V., Hildebrand M. \&Brzezinski M. 2000. Silicification in diatoms. Implication for growth. J. Phycol. 36, 821-840.

Märtz C.M., Meinhardt A-K., Schnetger B. \& Brumsack H-J.2015. Silica diagenesis and benthic fluxes in the Arctic Ocean. Mar. Chem. 171, 1-9.

Mattila J., Kankaanpaa H. \& Ilus E. 2006. Estimation of recent sediment accumulation rates in the baltic sea using artificial radionuclides Cs-137 and Pu-239,Pu-240 as time markers. Bor. Env. Res. 11(2), 95-107.

Meier M. 2007. Modeling the pathways and ages of inflowing salt- and freshwater in the Baltic sea. Est. Coast. Shelf Sci. 74, $610-627$.

Michalopoulos P. \& Aller R.C. 2004. Early diagenesis of biogenic silica in the Amazon delta: alteration, authigenic clay formation and storage. Geochim Cosmochim Acta 68,10611085

Mullin J. \& Riley J. 1955. The colorimetric determination of silicate with special reference to sea and natural waters. Anal. Chim. Acta 12, 162-176.

Mortimer C. 1941. The exchange of dissolved substances between mud and water in lakes, I and II. J Ecol 29, 280-329.

Mortimer C. 1942. The exchange of dissolved substances between mud and water in lakes, III and IV. J Ecol 30, 147-201 
Nelson D.M., Anderson R.F., Barber R.T., Brzezinski M.A., Buesseler K.O., Chase Z., Collier R.W., Dickson M.L., Francois R., Hiscock M.R., Honjo S., Marra J., Martin W.R., Sambrotto R.N., Sayles F.L. \& Sigmon D E. 2002. Vertical budgets for organic carbon and biogenic silica in the Pacific sector of the Southern Ocean, 1996-1998. Deep-Sea Res. II 49,1645-74

Norkko J, Gammal J., Hewitt J.E., Josefson A.B., Carstensen J. \& Norkko A. 2015. Seafloor ecoystem function relationships: in situ patterns of change across gradients of increasing hypoxic stress. Ecosystems 18,1424-1439.

Paasche E. 1980. Silicon content of five marine plankton diatom species measured with a rapid filter method. Limnol. Oceanogr. 25,474-480

Papush L. \& Danielsson A. 2006 Silicon in the marine environment: Dissolved silica trends. Est. Coast. Shelf Sci. 67, 53-66.

Papush L., Danielsson A. \& Rahm L. 2009. Dissolved silica budget for the Baltic Sea. J. Sea Res. 62, 31-41.

Presti M. \& Michalopoulos P. 2008. Estimating the contribution of the authigenic mineral component to the long-term reactive silica accumulation on the western shelf of the Mississippi River Delta. Cont. Shelf Res. 28,828-38

Rahm L., Conley D., Sandén P., Wulff F. \& Stålnacke P. 1996. Time series analysis of nutrient inputs to the Baltic Sea and changing DSi:DIN ratios. Mar. Ecol. Prog. Ser. $130,221-8$.

Ragueneau O., Gallinari M., Corrin L., Grandel S. , Hall P.O.J, Hauvespre A., Lampitt R.S., Rickert D., Stahl H ., Tengberg A. \& Witbaard R. 2001. The benthic silica cycle in the Northeast Atlantic: annual mass balance, seasonality, and importance of non-steady-state processes for the early diagenesis of biogenic opal in deep-sea sediments. Prog. Oceanogr. 50(1), 171-200.

Rantataro J. 1992. Mapping of seafloor deposits offshore Helsinki region. Helsingin seutukaavaliiton julkaisuja C 31, 84 pp. [in Finnish].

Reynolds C. 1984. The ecology of freshwater phytoplankton.Cambridge U.Press, Cambridge. $384 \mathrm{p}$.

Rutgers van der Loeff M., Anderson L., Hall P.O.J., Iverfeldt Å., Josefson A. , Sundby B. \& Westerlund S. 1984. The asphyxiation technique: an approach to distinguishing between molecular diffusion and biologically mediated transport at the sediment-water interface. Limnol. Oceanogr. 29,675-686. 
Sarazin G., Gaillard J-F., Philippe L. \& Rabouille C. 1995. Organic matter mineralisation in the pore water of a eutrophic lake (Aydat Lake, Puy de Dôme, France). Hydrobiologia $315,95-118$.

Savchuk O.P. 2002. Nutrient biogeochemical cycles in the Gulf of Riga: scaling up field studies with a mathematical model. J. Mar. Syst. 32, 253-280.

Savchuk O.P 2005. Resolving the Baltic Sea into seven subbasins: N and P budgets for 19911999. J. Mar. Syst. 56,1 -15.

Schulz H.D. 2006. Quantification of early diagenesis: dissolved constituents in pore water and signals in the solid phase. In: Schulz, H.D., Zabel, M. (Eds.), Marine Geochemistry, 2nd edition Springer-Verlag Berlin Heidelberg, pp. 73-124.

Siipola V. Lehtimäki M. \& Tallberg P. 2016. The effects of anoxia on Si dynamics in sediments. J. Soil Sed. 16, 266-279.

Spilling K. 2007. On the ecology of cold-water phytoplankton in the Baltic Sea. Phd thesis. Univ.Helsinki. W. \& A. De Nottbeck Foundation Sci. Rep. 31, 1-59.

Spilling K. \& Lindström M. 2008. Phytoplankton life cycle transformations lead to speciesspecific effects on sediment processes in the Baltic Sea. Cont. Shelf Res. 28,2488-2495.

Spilling K., Tamminen T., Andersen T. \& Kremp A. 2010. Nutrient kinetics modeled from timeseries of substrate depletion and growth: dissolved silicate uptake of Baltic Sea diatoms. Mar.Biol. 157, 427-436.

Srithongouthai S., Sonoyama Y-I., Tada K. \& Montani S. 2001. The influence of environmental variability on silicate exchange rates between sediment and water in a shallow-water coastal ecosystem, the Seto Inland Sea, Japan. Mar. Pollut. Bull. 47, 10-17.

Stipa T. 2002. Temperature as a passive isopycnal tracer in salty, spiceless oceans. Geophys. Res.Lett. 29, 1953.

Ståhl H. Tengberg A., Brunnegård J. \& Hall P.O.J. 2004. Recycling and burial of organic carbon in sediments of the Porcupine Abyssal Plain, NE Atlantic. Deep-Sea Res. I 51, 777-791.

Sundbäck K., Enoksson V., Graneli W. \& Pettersson K. 1991. Influence of Sublittoral Microphytobenthos on the Oxygen and Nutrient Flux between Sediment and Water - a Laboratory Continuous-Flow Study. Mar. Ecol. Prog. Ser. 74, 263-279.

Tallberg P., Lehtoranta J. \& Hietanen S. 2013. Silicate release from sand-manipulated sediment cores: biogenic or adsorbed Si? Silicon 5,67-74.

Tallberg P., Lukkari K., Räike A., Lehtoranta J. \& Leivuori M. 2009. Applicability of a sequential P fractionation procedure to Si in sediment. J. Soil Sed. 9,594-603. 
Tallberg P., Räike A., Lukkari K., Leivuori M., Lehtoranta J. \& Pitkänen H. 2012. Horizontal and vertical distribution of biogenic silica in coastal and profundal sediments of the Gulf of Finland (northeastern Baltic Sea). Bor. Env. Res. 17, 347-362.

Tengberg A. Almroth E. \& Hall P.O.J. 2003. Resuspension and its effects on organic carbon recycling and nutrient exchange in coastal sediments: in situ measurements using new experimental technology. J. Exp. Mar. Biol. Ecol. 285-286,119-142.

Tengberg A., Ståhl H., Gust G., Müller V., Arning U., Andersson H. \& Hall P.O.J. 2004. Intercalibration of benthic flux chambers I. Accuracy of flux measurements and influence of chamber hydrodynamics. Progr Oceanogr. 60, 1-28.

Tikkanen M. \& Oksanen J. 2002. Late Weichselian and Holocene shore displacement history of the Baltic Sea in Finland. Fennia 180, 1-2.

Treguer P. \& DeLaRocha C. 2013. The World Ocean Silica Cycle. Annu Rev Mar Sci 5, 477501.

Viktorsson L., Almroth Rosell E., Tengberg A., Vankevich R., Neelov I., Isaev A., Kravtsov V. \& Hall P.O.J. 2012. Benthic phosphorus dynamics in the Gulf of Finland, Baltic Sea. Aquat. Geochem. 18, 543-564.

Villnäs A., Norkko J., Hietanen S., Josefson A.B., Lukkari K. \& Norkko A. 2013. The role of recurrent disturbances for ecosystem multifunctionality. Ecology 94,2275-87.

Wasmund N., Nausch G. \& Feistel R. 2013. Silicate consumption: an indicator for long-term trends in spring diatom development in the Baltic Sea. J. Plankton Res. 35, 393-406.

Wasmund N., Tuimala J., Suikkanen S., Vandepitte L. \& Kraberg A. 2011. Long-term trends in phytoplankton composition in the western and central Baltic Sea. J. Mar. Syst. 87, 145159.

Wasmund N. \& Uhlig S., 2003. Phytoplankton trends in the Baltic Sea. ICES Journal of Marine Science: Journal du Conseil 60 (2), 177-186.

Willén E. 1991. Planktonic diatoms - an ecological review. Algological Studies 62, 69-106.

Wulff F., Perttilä M. \& Rahm L. 1994. Mass-balance calculations of nutrients and hydrochemical conditions in the Gulf of Bothnia, 1991. Aqua Fennica 24, 121-140.

Wulff F., Rahm L., Hallin A-K. \& Sandberg J. 2001. A nutrient budget model of the Baltic Sea. In: Wulff, F., Rahm, L., Larsson, P. (Eds.), A system analysis of the Baltic Sea. Ecological series 148. Springer-Verlag, Berlin, pp. 353-372.

Wulff F. \& Stigebrandt A. 1989. A time-dependent budget model for nutrients in the Baltic Sea. Global Biogeochemical Cycles 3, 53-78. 


\section{Highlights}

Recycling of Si via the sediment is important in the Gulf of Finland More than half of the sedimentation flux of $\mathrm{Si}$ is released back into the water column The permanent burial of $\mathrm{Si}$ in the Gulf amounts to ca $6 \mathrm{Gmol} \mathrm{a}{ }^{-1}$ 